\title{
The relationship between mineral composition, crystal structure and paragenetic sequence: the case of secondary Te mineralization at the Bird Nest drift, Otto Mountain, California, USA
}

\author{
Andrew G. Christy ${ }^{1, *}$, Stuart J. Mills ${ }^{2}$, Anthony R. KampF ${ }^{3}$, Robert M. Housley ${ }^{4}$, Brent Thorne ${ }^{5}$ and \\ Joe Marty ${ }^{6}$ \\ 1 Department of Applied Mathematics, Research School of Physics \& Engineering, Mills Rd, Australian National \\ University, Canberra, ACT 0200, Australia \\ 2 Geosciences, Museum Victoria, GPO Box 666, Melbourne 3001, Victoria, Australia \\ 3 Mineral Sciences Department, Natural History Museum of Los Angeles County, 900 Exposition Boulevard, \\ Los Angeles, CA 90007, USA \\ 4 Division of Geological and Planetary Sciences, California Institute of Technology, Pasadena, CA 91125, USA \\ 553898 S. Newport Circle, Bountiful, UT 84010, USA \\ 665199 E. Silver Oak Road, Salt Lake City, UT 84108, USA
}

[Received 1 February 2015; Accepted 19 May 2015; Associate Editor: Ian Graham]

\section{ABSTRACT}

An unusually diverse array of 25 secondary Te oxysalt minerals has been documented from Otto Mountain, California, and 18 of these from the Bird Nest drift sublocality. A paragenetic sequence for these minerals is proposed, using observed overgrowth relationships plus spatial association data and data from other localities. Apart from $\mathrm{Te}$ and $\mathrm{O}$, the components $\mathrm{Pb}, \mathrm{Cu}$ and $\mathrm{H}$ are essential in the majority of the minerals. The atomic $\mathrm{Cu} / \mathrm{Te}$ ratio decreases through the paragenetic sequence. This, and the occurrence of minerals with additional components such as $\mathrm{Cl}^{-}, \mathrm{CO}_{3}^{2-}, \mathrm{SO}_{4}^{2-}$ and $\mathrm{Fe}^{3+}$ at an intermediate stage, suggests nonmonotonic evolution of the parent fluids, reflecting differing access to or spatial distribution of various components.

For the minerals with known crystal structures, two alternative 'structural units' were identified, one consisting only of the $\mathrm{Te}^{4+}$ or $\mathrm{Te}^{6+}$ oxyanion, while the other also included small, strongly-bound cations such as $\mathrm{Cu}^{2+}$. The degree of polymerization for the Te oxyanion correlated with the paragenetic sequence: the monomeric tellurate anions of early minerals were replaced progressively by dimers, chains and sheet structures, which may relate to a decreasing abundance of the 'network modifying' $\mathrm{Cu}^{2+}$ cation, analogous to Bowen's discontinuous reaction series in igneous rock-forming silicates.

No relationship was seen between paragenetic order and the larger type of structural unit, or structural complexity as defined by information content. This contrasts with results in the literature for evaporite sulfates and pegmatite phosphates. While structure-paragenesis relationships may be widespread, the exact nature of such relationships may be different for different chemical systems and different paragenetic environments.

KeYwords: tellurate, tellurite, crystal structure, paragenetic sequence, complexity, secondary minerals, Otto Mountain, California.

\section{Introduction}

*E-mail: andrew.christy@anu.edu.au

DOI: $10 . \overline{1180 / \mathrm{minmag} .2016 .080 .001}$
THERE are many natural environments in which a large number of mineral species is inferred to have 
crystallized sequentially. These paragenetic sequences are often described in mineralogical literature, based on direct observations of textural relationships between species in mineral specimens. The comprehensiveness of such schemes has often been limited by lack of specimens that preserve the appropriate contextual data. Paragenetic sequences are often recorded as line diagrams, where the paragenesis may be segmented into categories such as 'magmatic', 'hydrothermal' and 'supergene', as undertaken for the pegmatites of Bridger Mountains, Wyoming by McLaughlin (1940), or into 'stages', as is the case for the variscite nodules from Fairfield, Utah described by Larsen (1942). Variations on these methods have been used for over half a century, especially in topological descriptions of mineral localities (cf. Keller, 1977; Birch and van der Heyden, 1988), where this kind of information can assist in identification of species in hand specimens.

Probably the oldest and most widely applied of such paragenetic schemes is the 'Discontinuous Reaction Series' of Bowen (1922), which systematizes the observation that different types of rockforming silicate minerals appear on the liquidus of a melt as it evolves in composition and decreases in temperature. The solution of silicate crystal structures and their classification by Bragg (1930) made it apparent that the silicate anions of the minerals varied systematically in their degree of polymerization as a function of liquidus temperature, ranging in topology from monomers and finite clusters, through infinite chains and sheets to threedimensional frameworks. It later became apparent that this gradation paralleled structural changes in the parent melt (cf. Mysen, 1983). Monomeric or oligomeric silicate anions are associated with low silica concentration, but a high concentration of cations such as $\mathrm{Mg}^{2+}$ that prefer six-fold coordination by oxygen through bonds of moderately high valence ( 0.3 valence units (vu), cf. Brown, 1981) and hence do not bond readily to bridging oxygen atoms within silicate polymers. Conversely, highly polymerized (alumino)silicate anions occur for high silica concentrations and counterions that have less charge and larger coordination number (i.e. less Lewis acidic), such as $\mathrm{Na}^{+}$and $\mathrm{K}^{+}$. Warren and Pincus (1940) coined the descriptions 'network forming', for the former type of counterion and 'network modifying' for the latter in synthetic glasses; these terms were later applied to silicate melts by Bottinga and Weill (1972). The idea of classifying minerals by structure, and particularly degree of polymerization, was later applied to other anion types, such as fluoroaluminates (Pabst, 1950) and borates (Christ, 1960).

The vast majority of mineral species are not 'rock forming' in that they are not major constituents of common igneous, metamorphic or sedimentary bulk compositions. Nevertheless, as noted above, there are environments, such as strongly fractionated pegmatites and the oxidized zones of ore bodies in which large numbers of rare species occur, and in which distinctive paragenetic sequences can be discerned. This is the case even for chemically complex and highly diverse metamorphosed and metasomatized ore bodies such as the Långban-type deposits of Sweden (Magnusson, 1930; Moore, 1970a; Jonsson and Broman, 2002).

Moore $(1970 b, 1973)$ made a pioneering attempt to correlate paragenetic order and crystal structure for pegmatite phosphates, somewhat analogous to the Bowen sequence for igneous rocks, which was later revisited in Moore (1982). This made use of a hierarchical classification of crystal structures that he was developing (Moore, 1970c). The possibility of understanding crystallization sequences in terms of structure has been a major driving force for developing further structural taxonomies since then (e.g. Hawthorne, 1983; Moore, 1984; Hawthorne, 1985, 1990 and references therein). Advances in these classifications have led to several structureparagenesis analyses for restricted compositional groups of minerals: evaporitic $\mathrm{Mg}$ sulfates (Hawthorne, 1992), vanadium minerals (Schindler et al., 2000), borates (Schindler and Hawthorne, $2001 a, b, c)$ and uranyl oxyhydroxides (Schindler and Hawthorne, 2004).

In general, structural classifications have used empirical classification of basic principles. Hawthorne (2014) summarizes the approach used in his earlier works, where the bonded network of a structure is divided on the basis of bond valence (Brown, 1981) into a tightly bound 'structural unit' and more weakly bound 'interstitial complex'. Explicit separation of octahedrally coordinated $M$ cations, usually of valence $2-3$, and tetrahedrally coordinated $T$ cations of higher valence (cf. Hawthorne, 1985, 1990), implies that the structural unit itself can be divided further to give an additional level of hierarchy. Note also that many large or infinitely extended structural units are polymers of distinctive oligomeric clusters termed 'fundamental building blocks' (FBB) (Hawthorne, $1983,1990,2014)$. It has been noted that only some of the geometrically possible FBB occur with any frequency, and that these particularly stable clusters may also be present in the parent fluid from which 
the minerals grew (cf. Moore, 1970b,c; Hawthorne, 1979; Moore, 1984; Burns, 1995; Hawthorne, 2014). Krivovichev et al. (2013) review structural hierarchies that are constructed using anion-centred coordination polyhedra rather than the more usual cation-centred polyhedra. This approach can be simpler when some of the cations are irregularlycoordinated species with stereoactive lone pairs.

More recently, methods for quantitatively calculating the complexity of crystal structures have been investigated by Estevez-Rams and González-Férez (2009), Steurer (2011) and Krivovichev (2013a,b, 2014). The complexity parameter of Krivovichev is based on the information content of the crystal structure. He found that structural complexity tends to increase with decreasing temperature and increasing pressure. In fig. 19 of Krivovichev (2013a), one of the phosphate parageneses of Moore (1973) is reworked to include structural complexity parameters, to show that hydrothermal alteration of primary phosphates results in the formation of minerals of greater complexity, which in turn can be reworked into even more complex minerals.

As part of a broader study of tellurium mineralogy, we have reinvestigated the stereochemistry of Te (Mills and Christy, 2013; Christy and Mills, 2013), and undertaken a comprehensive review of the structural diversity of Te oxysalt compounds (Christy et al., 2016). While undertaking the review, we discovered that many $\mathrm{Te}$ compounds have reoccurring structural motifs (Christy et al., 2016) such as the $\mathrm{Cu}_{2} \mathrm{Te}$ ribbon found in frankhawthorneite (Grice and Roberts, 1995), timroseite (Kampf et al., 2010e), paratimroseite (Kampf et al., 2010e) and bairdite (Kampf et al., 2013c), which suggested that Te oxysalt mineral structures form a structural hierarchy that might also correlate with paragenetic order, as do those noted above for other chemical classes of mineral. Testing this idea required a locality containing a large suite of Te minerals, and sufficient contact relationships between coexisting minerals for a paragenetic sequence to be deduced. The tellurium study was inspired in the first place by the current high rate of discovery of Te minerals. In particular: (1) between 2009 and 2015, 21 new secondary Te minerals and ten tellurides have been approved by the International Mineralogical Association; (2) of the secondary minerals, 14 come from the one locality: Otto Mountain, in California; (3) one of the remarkable facts about these minerals is that most of them have unique crystal structures.
The suite of Te oxysalt minerals from Otto Mountain is large enough and diverse enough in structure to recommend investigation of the relationship between structure and paragenetic sequence. Therefore, we reviewed the published data on the locality and its minerals, in order to collate textural observations which would allow us to construct a paragenetic sequence for the $\mathrm{Te}$ oxysalt minerals.

\section{Occurrence and paragenesis of Te oxysalt minerals at Otto Mountain}

Otto Mountain is a massif $\sim 2.5 \mathrm{~km}$ across, located on the northwest outskirts of the town of Baker, San Bernardino County, California (35.2774809 N, 116.098347 W). As a locality, it includes about two dozen distinct small workings that lie on the slopes of the mountain, such as the Aga mine and the Bird Nest drift. At the time of writing (January, 2015), the Mindat database (www.mindat.org) lists 86 valid mineral species for Otto Mountain, including primary sulfides of $\mathrm{Ag}, \mathrm{Cu}, \mathrm{Pb}$ and $\mathrm{Zn}$ plus the tellurides hessite $\left(\mathrm{Ag}_{2} \mathrm{Te}\right)$, cervelleite $\left(\mathrm{Ag}_{4} \mathrm{TeS}\right)$ and tetradymite $\left(\mathrm{Bi}_{2} \mathrm{Te}_{2} \mathrm{~S}\right)$. Secondary minerals include native gold and silver, Te-free arsenates, carbonates, chlorides, chromates, molybdates, phosphates, selenites, sulfates and vanadates, as well as the Te oxysalt minerals. All 14 new minerals which have Otto Mountain as their type locality contain essential Te. The mineralogy of Otto Mountain was recently reviewed by Housley et al. (2011). Since then, the four potentially new Te species reported in that article have been fully described, along with some others, and several other species have been identified that were already known from elsewhere. The current list of Te oxysalt minerals (Table 1) includes 25 species, if the two polytypes of khinite are counted as one. In practice, the khinite is almost always the $4 O$ polytype, although the $3 T$ structure (formerly 'parakhinite': Hawthorne et al. 2009) appeared to be intergrown with it on the type specimen of paratimroseite (Kampf et al. 2010e).

For the purposes of this paragenetic study, we are focusing on the most diverse single sublocality, the Bird Nest drift, which still has 60 mineral species, including $18 \mathrm{Te}$ oxysalt minerals. The Te oxysalt minerals known from other sublocalities on Otto Mountain are also included in the Table. However, they are not treated as fully present for several reasons: (1) As a geographically larger area is considered, the assumption becomes less valid that 
TABLE 1. Secondary Te minerals occurring at Otto Mountain. The valence state of Te is $6+$ unless otherwise stated.

\begin{tabular}{|c|c|c|}
\hline Name & Formula & Reference \\
\hline Agaite & $\mathrm{Pb}_{3} \mathrm{Cu}\left[\mathrm{TeO}_{5} \mathrm{OH}\right]\left(\mathrm{CO}_{3}\right)(\mathrm{OH})$ & *Kampf et al. (2013b) \\
\hline Andychristyite & $\mathrm{Pb} 2 \mathrm{Cu}_{2}\left[\mathrm{Te}_{2} \mathrm{O}_{10}\right] \cdot 2 \mathrm{H}_{2} \mathrm{O}$ & *Kampf et al. (2016) \\
\hline Bairdite & $\mathrm{Pb}_{2} \mathrm{Cu}_{4}\left[\mathrm{TeO}_{5} \mathrm{OH}\right]_{2}\left(\mathrm{SO}_{4}\right) \cdot \mathrm{H}_{2} \mathrm{O}$ & *Kampf et al. (2013c) \\
\hline Burckhardtite & $\mathrm{Pb}_{2}\left(\mathrm{Fe}^{3+} \mathrm{Te}\right)\left[\mathrm{AlSi}_{3} \mathrm{O}_{8}\right] \mathrm{O}_{6}$ & Housley et al. (2011); *Christy et al. (2015) \\
\hline Chromschieffelinite & $\mathrm{Pb}_{10}\left[\mathrm{Te}_{2} \mathrm{O}_{8}(\mathrm{OH})_{3}\right]_{2}\left[\mathrm{TeO}_{2}(\mathrm{OH})_{4}\right]_{2}\left(\mathrm{CrO}_{4}\right) \cdot 5 \mathrm{H}_{2} \mathrm{O}$ & *Kampf et al. (2012) \\
\hline Eckhardite & $\mathrm{Ca}_{2} \mathrm{Cu}_{2}\left[\mathrm{Te}_{2} \mathrm{O}_{10}\right] \cdot 2 \mathrm{H}_{2} \mathrm{O}$ & *Kampf et al. (2013d) \\
\hline Eztlite & $\mathrm{Pb}_{2} \mathrm{Fe}_{6}^{3+} \mathrm{Te}_{3}^{4+} \mathrm{TeO}_{15}(\mathrm{OH})_{10} \cdot 8 \mathrm{H}_{2} \mathrm{O}$ & Housley et al. (2011) \\
\hline Frankhawthorneite & $\mathrm{Cu}_{2}\left[\mathrm{TeO}_{4}(\mathrm{OH})_{2}\right]$ & XRD confirmed \\
\hline Fuettererite & $\mathrm{Pb}_{3} \mathrm{Cu}_{6}\left[\mathrm{TeO}_{6}\right](\mathrm{OH})_{7} \mathrm{Cl}_{5}$ & *Kampf et al. $(2013 a)$ \\
\hline Housleyite & $\mathrm{Pb}_{6} \mathrm{Cu}\left[\mathrm{Te}_{4} \mathrm{O}_{18}(\mathrm{OH})_{2}\right]$ & *Kampf et al. (2010b); Housley et al. (2011) \\
\hline Khinite-3T, $-4 O$ & $\mathrm{PbCu}_{3}\left[\mathrm{TeO}_{6}\right](\mathrm{OH})_{2}$ & $\begin{array}{l}\text { *Burns et al. (1995); *Cooper et al. (2008); } \\
\text { Hawthorne et al. (2009); Kampf et al. } \\
\text { (2010e); Housley et al. (2011) }\end{array}$ \\
\hline Kuksite & $\mathrm{Pb}_{3} \mathrm{Zn}_{3}\left[\mathrm{TeO}_{6}\right]\left(\mathrm{PO}_{4}\right)_{2}$ & *Mills et al. (2010); EDS confirmed \\
\hline Kuranakhite & $\mathrm{PbMn}^{4+} \mathrm{TeO}_{6}$ & Housley et al. (2011) \\
\hline Markcooperite & $\mathrm{Pb}_{2}\left[\left(\mathrm{U}_{0.75} \mathrm{Te}_{0.25}\right) \mathrm{TeO}_{8}\right]$ & *Kampf et al. (2010d); Housley et al. (2011) \\
\hline Mcalpineite & $\mathrm{Cu}_{3}\left[\mathrm{TeO}_{6}\right]$ & ${ }^{*}$ Carbone et al. (2013) EDS confirmed \\
\hline Mojaveite & $\mathrm{Cu}_{6}\left[\mathrm{TeO}_{4}(\mathrm{OH})_{2}\right](\mathrm{OH})_{7} \mathrm{Cl}$ & *Mills et al. (2014) \\
\hline Ottoite & $\mathrm{Pb}_{4}\left[\mathrm{Te}_{2} \mathrm{O}_{10}\right]$ & Kampf et al. (2010a); Housley et al. (2011) \\
\hline Paratimroseite & $\mathrm{PbCu}_{2}\left[\mathrm{TeO}_{6}\right] \cdot \mathrm{H}_{2} \mathrm{O}$ & *Kampf et al. (2010e); Housley et al. (2011) \\
\hline Sonoraite & $\mathrm{Fe}^{3+}\left[\mathrm{Te}^{4+} \mathrm{O}_{3}\right](\mathrm{OH}) \cdot \mathrm{H}_{2} \mathrm{O}$ & XRD confirmed \\
\hline Telluroperite & $\mathbf{P b}_{2}\left[\left(\mathrm{~Pb}^{2+} \mathrm{Te}^{4+}\right) \mathrm{O}_{4}\right] \mathrm{Cl}_{2}$ & *Kampf et al. (2010f); Housley et al. (2011) \\
\hline Thorneite & $\mathrm{Pb}_{6}\left[\mathrm{Te}_{2} \mathrm{O}_{10}\right]\left(\mathrm{CO}_{3}\right) \mathrm{Cl}_{2} \cdot \mathrm{H}_{2} \mathrm{O}$ & *Kampf et al. (2010c); Housley et al. (2011) \\
\hline Timroseite & $\mathrm{Pb}_{2} \mathrm{Cu}_{5}\left[\mathrm{TeO}_{6}\right]_{2}(\mathrm{OH})_{2}$ & *Kampf et al. (2010e); Housley et al. (2011) \\
\hline Xocometatlite & $\mathrm{Cu}_{3} \mathrm{TeO}_{4}(\mathrm{OH})_{4}$ & EDS/XRD confirmed \\
\hline Yafsoanite & $\mathrm{Ca}_{3} \mathrm{Zn}_{3}\left[\mathrm{TeO}_{6}\right]_{2}$ & *Mills et al. (2010); EDS confirmed \\
\hline
\end{tabular}

Bold indicates minerals occurring at the Bird's Nest drift.

* Indicates a reference including a crystal structure.

all sublocalities and specimens share the same history of fluid compositions and physical conditions. (2) Three of the five additional minerals contain essential chemical components which are not present in any of the Bird Nest drift minerals. Kuranakhite contains $\mathrm{Mn}^{4+}$, yafsoanite has $\mathrm{Zn}$, and kuksite has both $\mathrm{Zn}$ and $\mathrm{P}$ (Table 1). The occurrence of these minerals may be determined predominantly by availability of these unusual components, and hence serves as an example of chemical difference between nearby sublocalities as mentioned above, while adding little to the discussion below. (3) There is almost no data available on contact/overgrowth relationships between these Te minerals and others of the type that is discussed in the next section of this paper.

We note that the secondary minerals of Otto Mountain form in fractures in brecciated quartz veins, which are then overgrown by quartz and sealed to form closed microenvironments. The assemblage of minerals found in any single such fracture is thus a function of both: (1) the composition of the open-system fluid that was sampled at the time of microenvironment closure, which in turn reflects the primary minerals that were being oxidized at the time, and the solubility of their oxidation products and (2) the subsequent closedsystem evolution of the fluid in the microenvironment as it cools and fractionates out various crystalline products. In general, the early-crystallizing minerals will be less soluble, as a result of being more stable thermodynamically and/or having a greater content of the components that are most abundant in the fluid. Conversely, more soluble minerals and those containing components that are scarcer in solution would be expected to form later.

It will be seen below that consistent timing relationships between different species are observed, which can be ascribed to populations of closedsystem assemblages tending to have similar 
compositions and to evolve in consistent ways. Superimposed on that pattern, wholesale appearance and disappearance of components from the local closed systems is also evident, which is best explained as arising from longer-term stochastic change in the open-system fluid supply as different sources are tapped. Temporal relationships arising from both causes can be linked to gather a large number of minerals into a single paragenetic flowchart, as undertaken in this study. Such a unified chart summarizes the changes to mineralization that are driven by both local and more regional changes in the fluid, but do not imply that a full sequence from earliest minerals to latest would ever be expected to occur in a single microenvironment.

\section{Paragenetic data for minerals}

A feature of mineral chemistry that is immediately apparent from Table 1 is that the constituent chemical elements (other than $\mathrm{Te}$ and $\mathrm{O}$ ) divide into two groups. $\mathrm{Pb}, \mathrm{Cu}$ and $\mathrm{H}$ are each present in a majority of Bird Nest drift Te minerals (12/18, 11/ 18 and 12/18 cases, respectively), with six minerals containing the combination $\mathrm{Pb}+\mathrm{Cu}+\mathrm{H}$. Conversely, $\mathrm{Cl}$ occurs in only four minerals, $\mathrm{Fe}$ in two, and $\mathrm{C}, \mathrm{Al}, \mathrm{Si}, \mathrm{S}, \mathrm{Ca}, \mathrm{Cr}$ and $\mathrm{U}$ in one each. The occurrence of minerals containing the latter group of elements may be determined largely by the availability of those elements in the local microenvironment (as noted above, when considering the absence of $\mathrm{Zn}$ and Mn minerals at the Bird Nest drift). However, the large group of $\mathrm{Pb} / \mathrm{Cu} / \mathrm{H}$ minerals suggests that $\mathrm{Pb}$ and $\mathrm{Cu}$ were widely available throughout the supergene oxidation history of the deposit. It will be seen that temporal relationships exist between the various $\mathrm{Pb}-\mathrm{Cu}-\mathrm{Te}$ phases, whose crystallization order would have been determined by closed-system evolution of the fluid composition.

The rarer Te minerals often grew by themselves on quartz matrix, without contacting other Te minerals. This presumably reflects their restricted conditions of formation and/or availability of a special chemical component (e.g. $\mathrm{Cr}$ for chromschieffelinite). However, at least some contact and overgrowth relationships were observed for most Te minerals, which allow us to place them in order of crystallization sequence. The observational data are collated below, with some examples shown in Fig. 1. Mere coexistence on the same specimen is not taken to necessitate simultaneity of crystallization, although close spatial association of the rare minerals does suggest that similar restrictive conditions were met for their growth, and is used below to infer near-simultaneity of crystallization.

Khinite is the most abundant of the Te secondary minerals, and also appears to be the earliest: it occurs within millimetres of fresh galena (Housley et al. 2011). There is much evidence that khinite predated timroseite (e.g. Fig. $1 a$ and Mindat photograph 291189, B.T.) [Mindat photos available at http:// www.mindat.org/photo-xxxxxx.html where $\mathrm{xxxxxx}$ is the photo number], but also some that it continued to grow with or after timroseite (e.g. figs 13, 18 and 23-25 in Housley et al., 2011) and mcalpineite. Khinite also may predate thorneite (e.g. figs. 16-17 in Housley et al., 2011 and Mindat photos 291039, 362305 and 451178 , B.T.) or postdate thorneite (Mindat photo 451179, B.T.), but predates frankhawthornite (Fig. 1b).

Timroseite is fairly ubiquitous and rather early, first appearing while khinite was still crystallizing (see above). It usually predates mcalpineite (Fig. 1c) but may postdate it, and always predates markcooperite (Fig. 1d and Mindat photo 288660, J.M.). Paratimroseite is a rare mineral, synchronous with, or possibly predating, timroseite (e.g. fig 13 in Housley et al., 2011). It predates markcooperite (e.g. Mindat photo 288661, J.M.).

Mojaveite is rare. It is overgrown by mcalpineite (e.g. fig. 6 in Mills et al., 2014), and is associated spatially with all the minerals above, plus burckhardite and thorneite (Mills et al., 2014) and telluroperite (B.T. specimen).

Burckhardtite postdates khinite (B.T. specimen) and is associated with timroseite (e.g. Mindat photo 291167, B.T.) and mojaveite (above).

Telluroperite is associated with khinite, timroseite and mojaveite at the Bird Nest drift (see above), and at the E3 site appears to have grown simultaneously with timroseite and in association with khinite.

Eztlite is usually altered, but pristine crystals are associated with telluroperite (Housley et al., 2011). It usually grows on goethite, while nearby khinite and timroseite are on or in vein quartz, suggesting that the eztlite is very late.

Mcalpineite is a widespread mineral that may grow after or before khinite and timroseite, and postdates mojaveite (see above). At the Centennial Eureka mine, Utah, it is a substrate for frankhawthorneite (e.g. Mindat photo 189422, Anatoly Kasatkin).

Xocometatlite usually occurs as isolated spherules at most of its localities. The Bird Nest drift is no exception, so contacts with other Te minerals are 

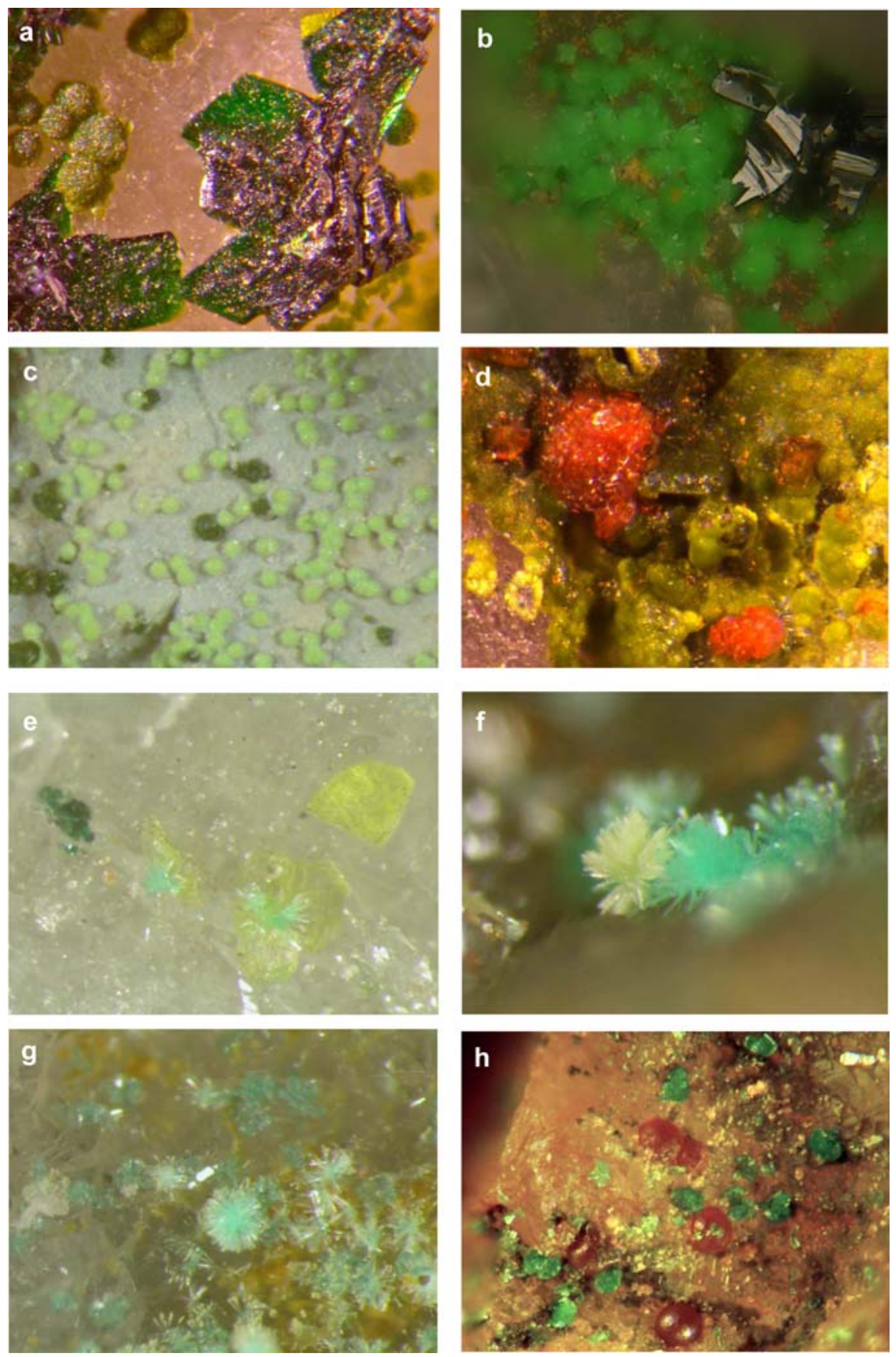

FIg. 1. Optical micrographs illustrating overgrowth relationships of Te oxysalt minerals from the Bird Nest drift. (a) Olivegreen balls of timroseite on dark green khinite crystals. FOV width $=4 \mathrm{~mm}$. (b) Bright green frankhawthorneite on khinite. FOV $=2 \mathrm{~mm}$. (c) Light green balls of mcalpineite on darker timroseite. FOV $=1 \mathrm{~mm}$. (d) Orange markcooperite on greenyellow timroseite. FOV $=2.5 \mathrm{~mm}$. (e) Light green needles of eckhardite on yellow thorneite. FOV $=0.75 \mathrm{~mm}$. $(f)$ Spray of pale yellow ottoite on green eckhardite. Darker green khinite also visible. FOV $=0.75 \mathrm{~mm}$. $(g)$ Eckhardite on larger bluegreen crystals of housleyite. FOV $=1 \mathrm{~mm}$. (h) Green housleyite on orange balls of markcooperite. FOV $=4 \mathrm{~mm}$. 
lacking. However, it overgrows mcalpineite at the Centennial Eureka mine, Utah (e.g. Mindat photo 279045, Jeff Weissman).

Frankhawthorneite is rare, and postdates khinite at the Bird Nest drift. It is also later than mcalpineite at the Centennial Eureka mine (see above), which is its type locality (Roberts et al., 1995).

Thorneite is a rare mineral that usually postdates khinite, although later khinite may overgrow it (see above). Thorneite predates eckhardite (Fig. 1e).

Chromschieffelinite is a very rare phase that grew after khinite and is associated with thorneite (B.T. specimen).

Fuettererite is a very rare mineral that predates its associate bairdite (e.g. Mindat photos 549726, B.T. and 586536, Luigi Chiappino). At its type locality, the NE2 vein site on Otto Mountain, it is associated with telluroperite (Kampf et al. 2013a).

Bairdite postdates fuettererite (see above).

Eckhardite postdates thorneite (see above), but predates ottoite (Fig. $1 f$ ), housleyite (e.g. Mindat photos 291168 and 298039, B.T.) and markcooperite (e.g. Mindat photos 456356 and 470274, B.T.). The latter two relationships were also seen in Aga mine material (e.g. Mindat photo 529325, B.T.). Some examples are known of eckhardite growing on top of housleyite (Fig. $1 \mathrm{~g}$ ). As eckhardite is the only mineral with essential $\mathrm{Ca}$ in this suite of $\mathrm{Te}$ oxyminerals, this may imply a prolonged growth period for eckhardite due to higher than usual $\mathrm{Ca}$ activity.

Ottoite occurs later than eckhardite (see above), but predates housleyite (e.g. Mindat photos 346251 and 456350, B.T.) and markcooperite (e.g. Mindat photos 456361 and 456358 , B.T.). Ottoite also precedes housleyite at the Aga mine (e.g. Mindat photo 347264 , B.T.).

Housleyite is a rather late mineral. It postdates timroseite (e.g. fig. 5 in Housley et al., 2011), eckhardite and ottoite (see above). In general, housleyite precedes markcooperite (e.g. fig. 5 in Housley et al., 2011 and Mindat photo 456350, B.T.), although it may continue to grow after markcooperite (Fig. 1h). Consistent with these observations, it also postdates eckhardite (e.g. Mindat photos 529325, B.T.) and ottoite (e.g. Mindat photos 347264 , B.T.) at the Aga mine.

Markcooperite is a rare, late-crystallizing mineral which postdates timroseite, paratimroseite and most housleyite (e.g. figs 5 and 8-9 in Housley et al., 2011 and Mindat photos 288658, 288660, 288661, J.M. and 456350 , B.T.). It also overgrows eckhardite and ottoite (see above) at the Bird Nest drift and eckhardite at the Aga mine (e.g. Mindat photos 529325, B.T.).

Several well-defined sequences of minerals can be deduced, the most complete being the sequence khinite $\leftrightarrow$ thorneite $\rightarrow$ eckhardite $\rightarrow$ ottoite $\rightarrow$ housleyite $\leftrightarrow$ markcooperite. The first and last links of this chain are bidirectional, as khinite appears to be a rather stable mineral which crystallizes over a considerable interval, and hence can grow simultaneously with or after the normally later phases timroseite and thorneite. Housleyite, similarly, usually precedes markcooperite, but can continue to grow on the latter mineral. Intermediate steps of the chain are not always present, so for instance, housleyite has been observed growing directly on eckhardite, and markcooperite on ottoite. The various partial chains substantiated by overgrowth observations can be linked, using more tentative spatial association data or observations from other localities, to produce a single network that includes all the Bird Nest drift Te oxysalt minerals (Fig. 2). All the contact relationships of this study are consistent with sequential deposition of the contacting minerals; no rounded or rough crystal edges have been observed that would evidence resorption of previously-crystallized phases.

\section{Correlation between paragenetic order, composition and structure}

The paragenetic flowchart of Fig. 2 can be used to examine whether the Te oxysalt minerals of the Bird Nest drift show any temporal trends in chemical composition or crystal structure.

\section{Chemical composition}

It was noted above that the majority of oxysalt minerals at the Bird Nest drift contain at least one of $\mathrm{Pb}, \mathrm{Cu}$ or $\mathrm{H}$. In fact, eight out of the 18 minerals belong exclusively to the $\mathrm{Pb}-\mathrm{Cu}-\mathrm{Te}-\mathrm{O}-\mathrm{H}$ chemical subsystem. The other nine chemical elements that occur sporadically as essential components are distributed in a decidedly non-random fashion through the paragenetic sequence deduced above. In Fig. 3, the arrow topology of Fig. 2 has been reproduced, but for simplicity, the mineral names and formulae have been replaced with three-letter symbols analogous to those of Kretz (1983) or Whitney and Evans (2010). The following features are immediately apparent. (1) The sole uranium mineral, markcooperite, is the last to crystallize. (2) The four minerals that contain $\mathrm{Cl}$ tend to be 


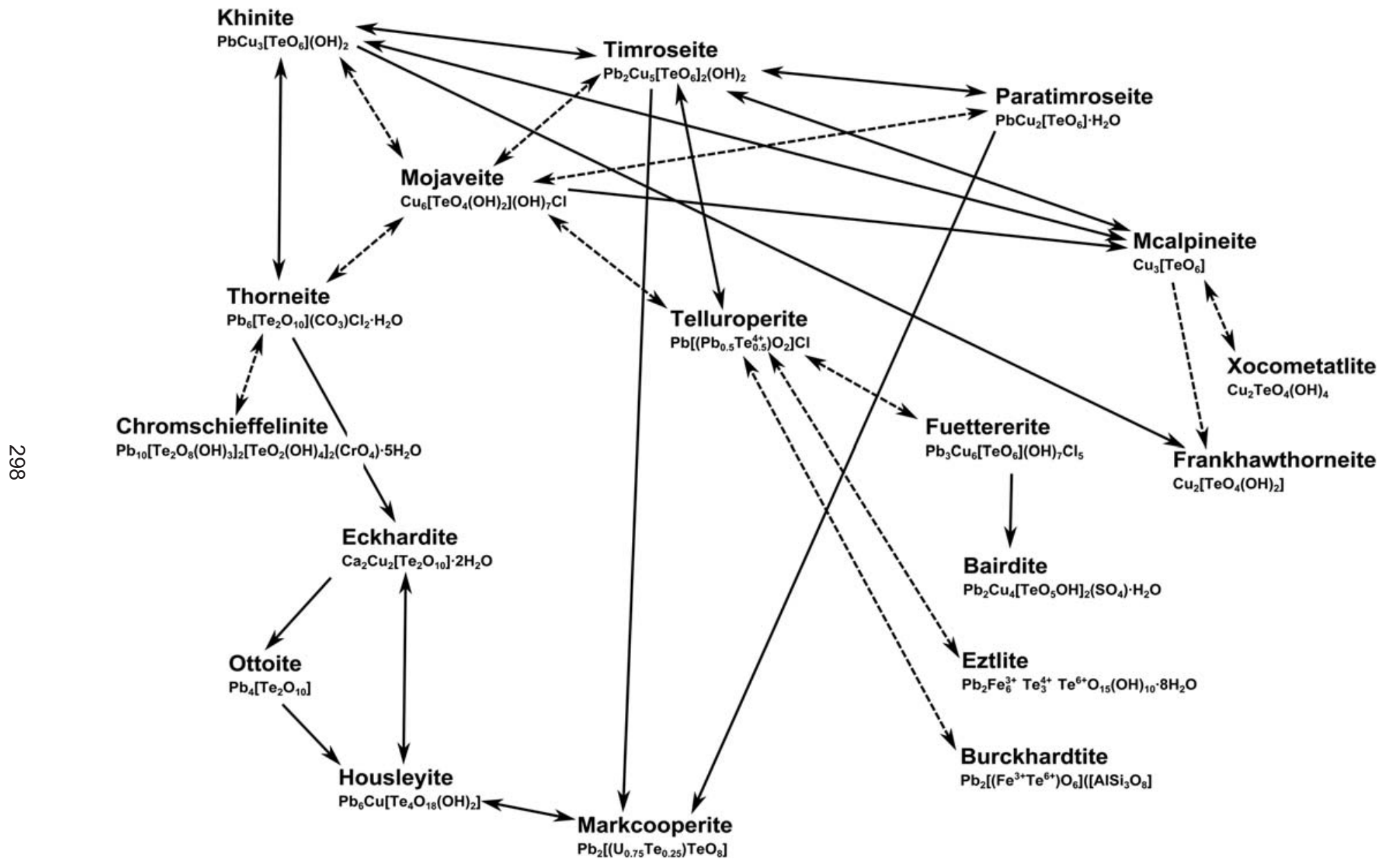

FIg. 2. Paragenetic sequence for Te oxysalt minerals at the Bird Nest drift. Solid arrows represent overgrowth relationships observed for the Bird Nest drift. Dashed arrows are less certain, representing data from other localities or spatial proximity without an overgrowth. 


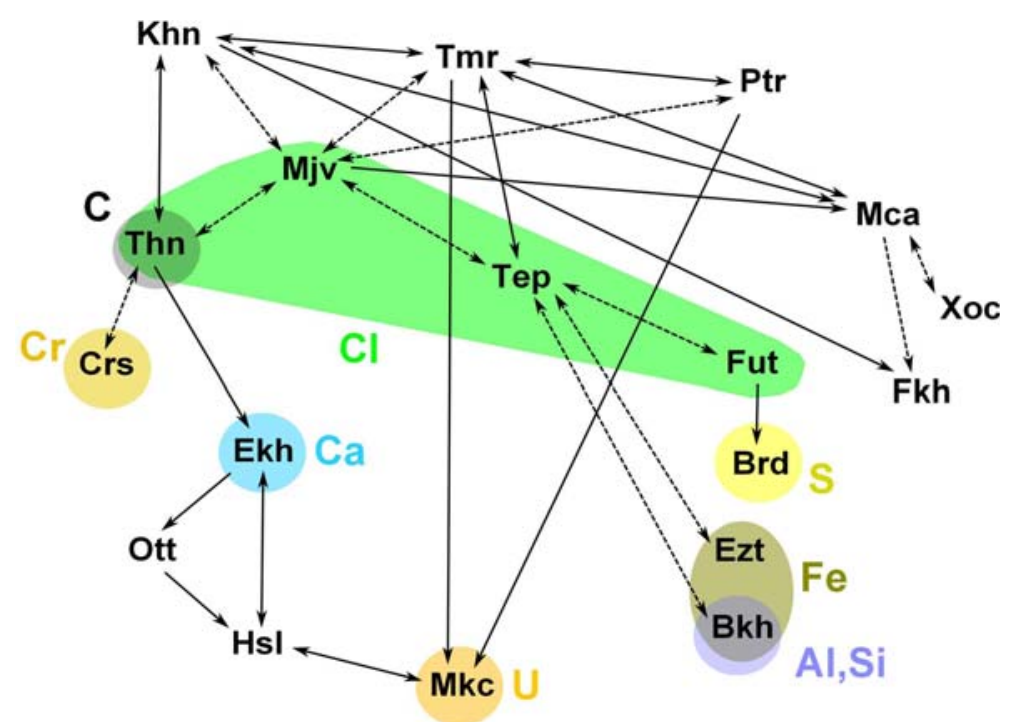

FIG. 3. Distribution of the elements that occur sporadically as essential components of Te oxysalt minerals. Three-letter symbols represent the mineral names in the corresponding positions in Fig. 2.

spatially associated with each other, and all appear to have crystallized at an intermediate stage in the overall sequence. (3) The other sporadic components, $\mathrm{C}, \mathrm{Al}, \mathrm{Si}, \mathrm{S}, \mathrm{Cr}$ and $\mathrm{Fe}$, all occur in minerals that are associated with $\mathrm{Cl}$-bearing species. This is probably due to the more saline fluid dissolving and transporting greater concentrations of these components. It is interesting to note that this intermediate band also includes telluroperite and eztlite, the only minerals of this study that contain $\mathrm{Te}^{4+}$ as well as or instead of $\mathrm{Te}^{6+}$. Note that yet other components may be present, which do not form secondary minerals with Te. For instance, eckhardite occurs in specimens with khinite, timroseite, paratimroseite, thorneite, ottoite and housleyite, but also with gold, chlorargyrite and iodargyrite, while bairdite and fuettererite occur associated with not just khinite and timroseite, but also boleite and atacamite. Evidently, the Au, Ag and I in the parent fluid do not form minerals with Te, but crystallize as Te-free phases instead, and some of the $\mathrm{Cl}$ forms additional Te-free chlorides. However, because $\mathrm{I}$ is present at the locality, there is scope for finding bluebellite, $\mathrm{Cu}_{6}\left[\mathrm{I}^{5+} \mathrm{O}_{3}(\mathrm{OH})_{3}\right](\mathrm{OH})_{7} \mathrm{Cl}$, the iodate analogue of mojaveite (Mills et al., 2014), at Otto Mountain.

This distribution pattern suggests strongly that the composition of parent fluids evolved through time from (1) a state of relatively low chloride activity to (2) high chloride activity, precipitating minerals that contain $\mathrm{Cl}$ and other unusual components, to (3) back to low chloride activity, with only Cl-free minerals and (4) a final stage of $\mathrm{U}$ mineralization, which may imply that redox potential only then became high enough to oxidize $\mathrm{U}^{4+}$ in precursor minerals, thus mobilizing it as relatively soluble $\mathrm{U}^{6+}$ (i.e. change in supply from the open system) or may just reflect delay of markcooperite crystallization due to intrinsically low concentrations of $\mathrm{U}^{6+}$ (i.e scarcity in the closed system). At the Bird Nest drift, the single secondary $\mathrm{U}$ mineral formed after the suite of $\mathrm{Cu}$ secondaries, which contrasts with the pattern seen at other localities such as Lake Boga, Victoria, Australia. There, geochronology has shown early phosphates (fluorapatite and monazite-(Ce)/cheralite) and primary uraninite to have a similar Devonian age to the host granite (Mills et al. 2008), separated widely in time from a diverse array of secondary minerals formed by reaction with oxidizing meteoric water in the Quaternary (Birch et al. 2011). The overall paragenetic sequence at Lake Boga has a unique $\mathrm{Ca}-\mathrm{Cu}-\mathrm{U}$ phosphate (ulrichite) as one of the earlier crystallizing secondary minerals along with turquoise, and both $\mathrm{Cu}$-free uranyl minerals (saléeite) and $\mathrm{U}$-free $\mathrm{Cu}$ minerals (pseudomalachite) among the latest phases (Birch, 1993; Birch et al. 2011). Hence, $\mathrm{Cu}$ and $\mathrm{U}$ were both available and co-crystallizing as phosphate minerals throughout the sequence. This difference 

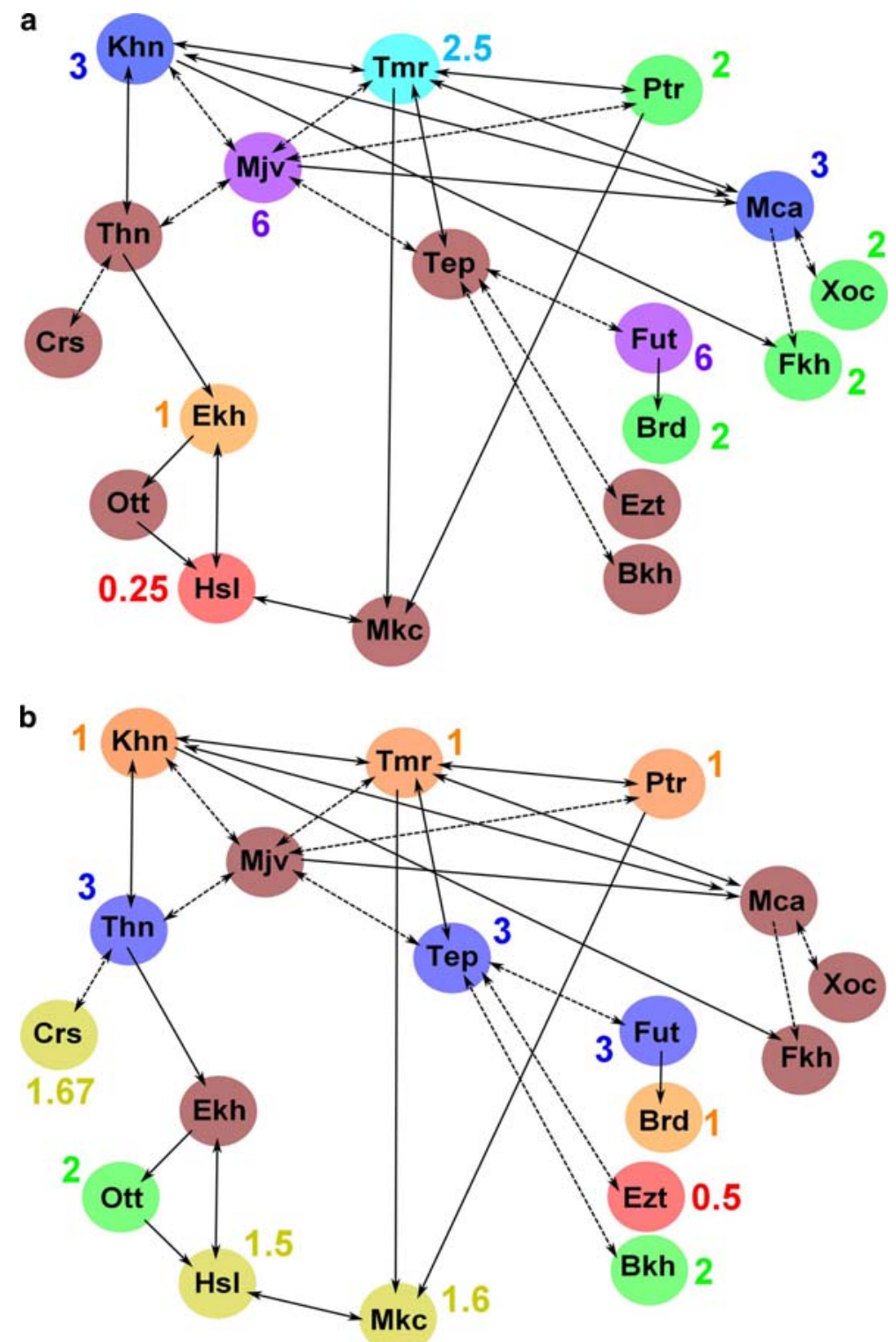

FIG. 4. (a) Atomic $\mathrm{Cu} / \mathrm{Te}$ ratio for the minerals of Figs 2-3. (b) Atomic $\mathrm{Pb} / \mathrm{Te}$ ratio. Violet/blue colours indicate high ratios, redder hues indicate low ratios and brown indicates zero.

from Otto Mountain is a good illustration of how the relative availabilities of different components can be controlled by different physical conditions.

Out of the three cations $\mathrm{Pb}, \mathrm{Cu}$ and $\mathrm{H}$ that are widespread in Bird Nest drift Te oxysalt minerals, only $\mathrm{Cu}$ shows any tendency to vary systematically down the sequence. Figure $4 a$ shows the atomic
$\mathrm{Cu} / \mathrm{Te}$ ratio for the minerals of Fig. 2, and it is clear that early minerals tend to be $\mathrm{Cu}$ rich $(\mathrm{Cu} / \mathrm{Te}=2-6)$ while later minerals are $\mathrm{Cu}$ poor $(\mathrm{Cu} / \mathrm{Te}=0-1)$. This is likely to represent progressive depletion of $\mathrm{Cu}$ in closed local microenvironments. No such tendency is discernible for $\mathrm{Pb}$ content (Fig. 4b), where the earliest minerals all have $\mathrm{Pb} / \mathrm{Te}=1$ and the latest minerals have $\mathrm{Pb} / \mathrm{Te}=1.5-2$, while 

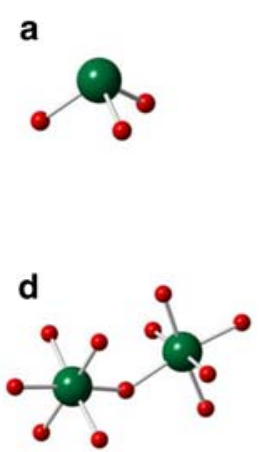

b

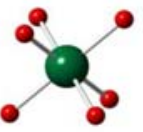

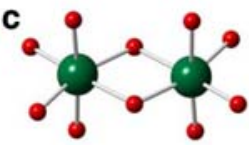

e

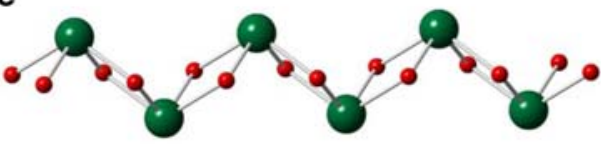

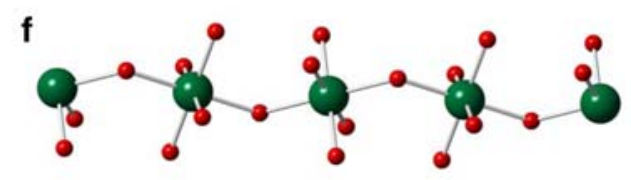

g

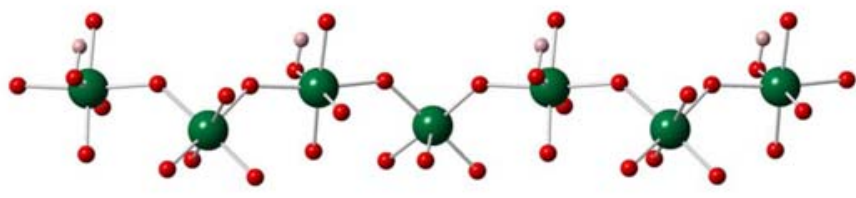

$\mathbf{h}$

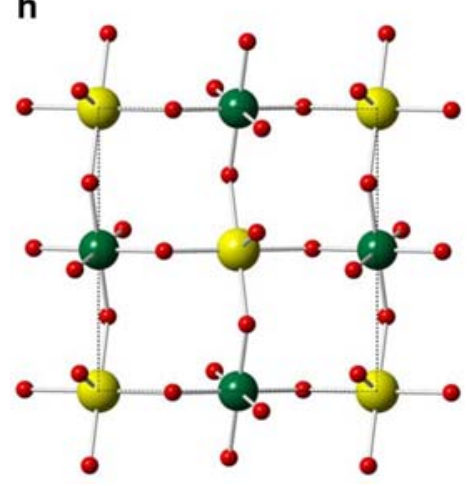

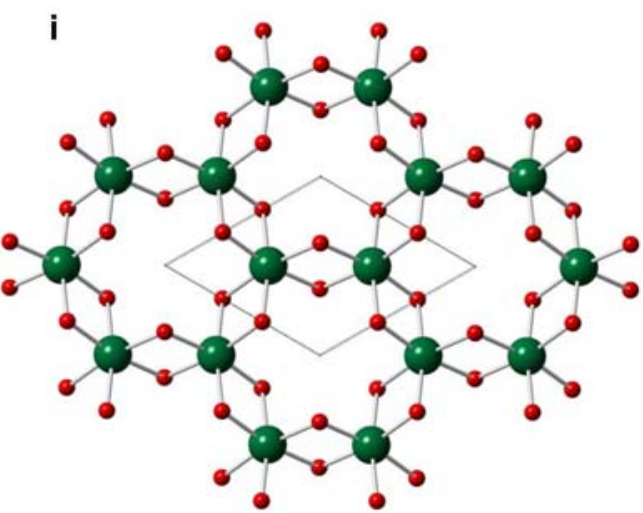

Fig. 5. Te-O anions for the minerals of Table 2. Large green spheres are Te atoms, large yellow spheres are (U,Te), small red spheres are $\mathrm{O} . \mathrm{H}$ are very small pink spheres, when located. $(a)\left[\mathrm{Te}^{4+} \mathrm{O}_{3}\right]^{2-}$ pyramid of sonoraite. $(b)\left[\mathrm{Te}^{6+} \mathrm{O}_{6}\right]^{6-}$ octahedron of seven minerals in Table 2, also found in protonated form in agaite, bairdite, frankhawthorneite and mojaveite. (c) Edge-sharing dimer $\left[\mathrm{Te}_{2} \mathrm{O}_{10}\right]^{8-}$ of andychristyite, eckhardite and thorneite. $(d)$ Corner-sharing dimer $\left[\mathrm{Te}_{2} \mathrm{O}_{8}(\mathrm{OH})_{3}\right]^{7-}$ of chromschieffelinite. (e) Edge-sharing zweier chain of pyramids $\left[\left(\mathrm{Pb}_{0.5}^{2+} \mathrm{Te}_{0.5}^{4+}\right)_{2} \mathrm{O}_{4}\right]^{2-}$ of telluroperite. $(f)$ Corner-sharing zweier chain of octahedra $\left[\mathrm{Te}_{2} \mathrm{O}_{10}\right]^{8-}$ of ottoite. $(g)$ Corner-sharing vierer chain $\left[\mathrm{Te}_{4} \mathrm{O}_{18}(\mathrm{OH})_{2}\right]^{14-}$ of housleyite. (h) Corner-sharing sheet of markcooperite $\left[(\mathrm{U}, \mathrm{Te})^{6+} \mathrm{Te}^{6+} \mathrm{O}_{8}\right]^{4-}$. (i) Edge-sharing sheet $\left[\left(\mathrm{Fe}_{0.5}^{3+} \mathrm{Te}_{0.5}^{6+}\right)_{2} \mathrm{O}_{6}\right]^{3-}$ of burckhardtite. 


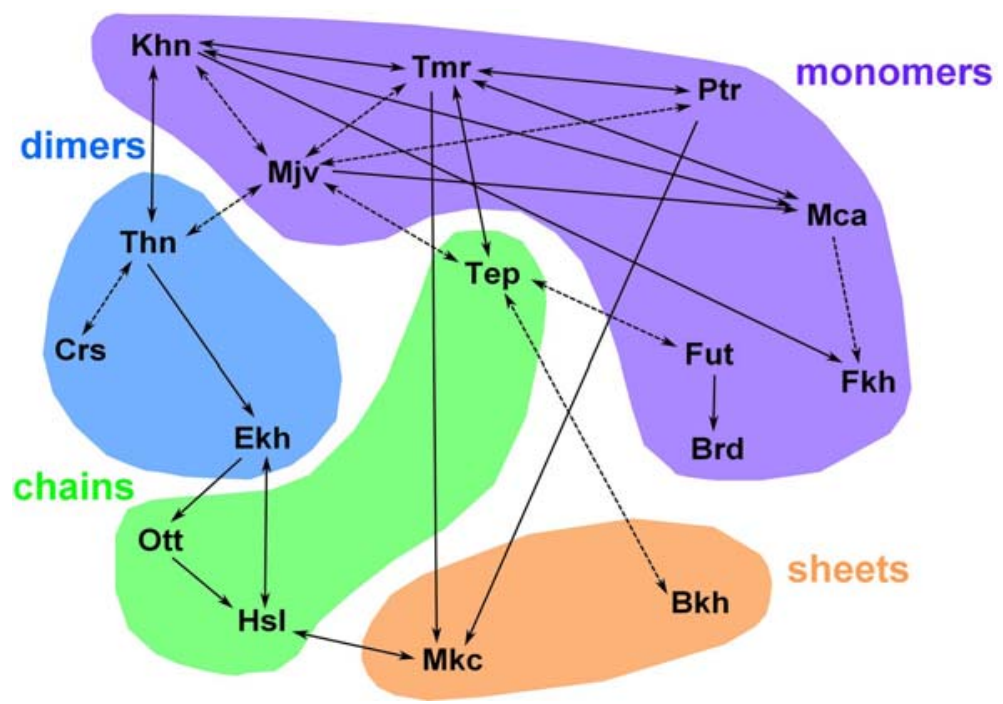

FIG. 6. Degree of polymerization of the Te anion, plotted on the paragenetic flowchart.

intermediate species may have a much larger or smaller $\mathrm{Pb} / \mathrm{Te}$ ratio. Similarly, no systematic variation down the sequence was seen for $\mathrm{H} / \mathrm{Te}$, or for ratios such as $\mathrm{Cu} / \mathrm{Pb}$. The distinctive time dependence of $\mathrm{Cu}$ activity relative to $\mathrm{Pb}$ and $\mathrm{Te}$ suggests that the $\mathrm{Cu}$ was derived from a distinct source in the host granite, that was spatially smaller or to which access was more restricted.

\section{Crystal structure}

For this study, we are particularly interested in the degree of polymerization of the more strongly bonded part of the crystal structure, which always includes the Te atom in the minerals of this study. Do these 'structural units' (Hawthorne, 2014) consist of monomeric Te oxyanions or finite oligomers, or do such FBB link to form infinitely

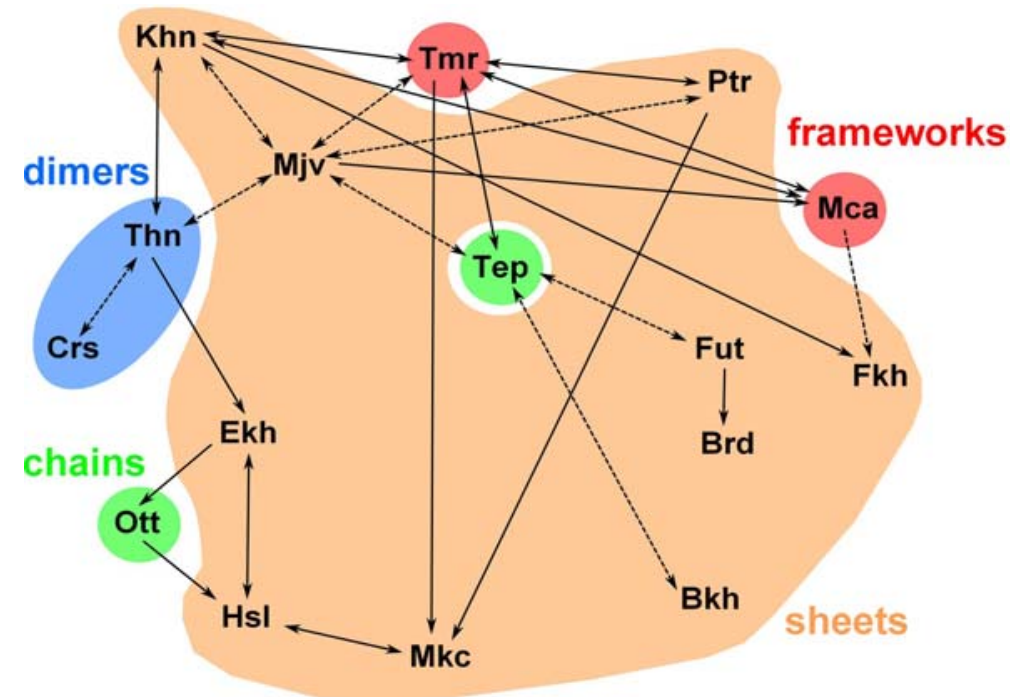

FIG. 7. Polymerization of the greater structural unit that incorporates $\mathrm{Cu} / \mathrm{Fe}$. 


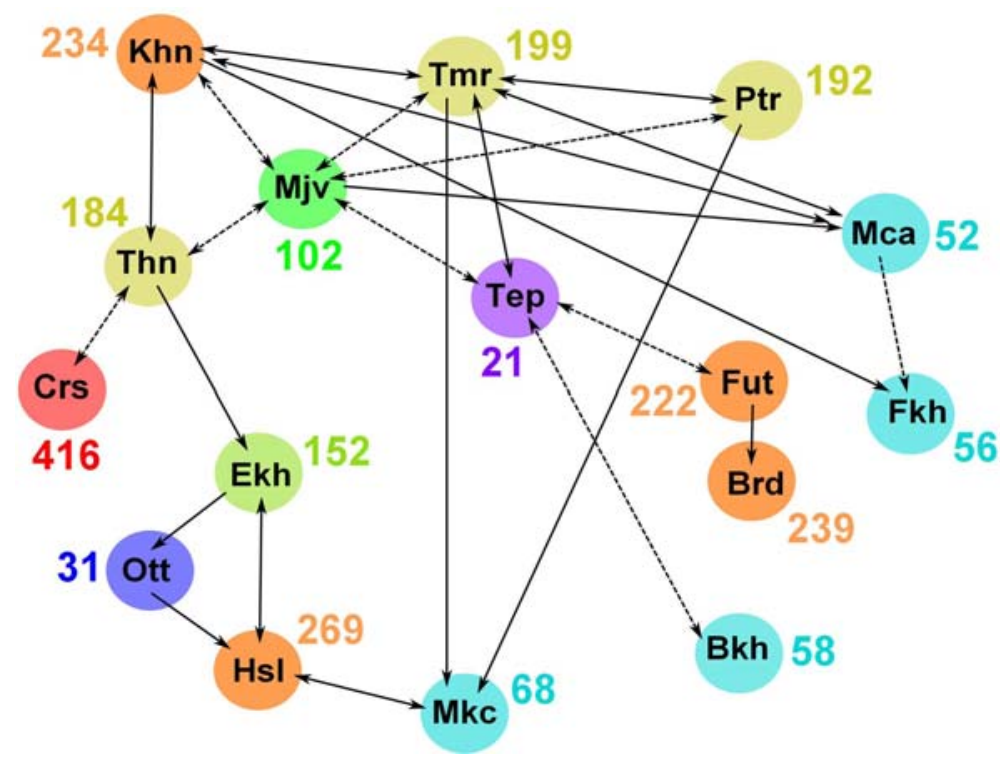

FIG. 8. Structural complexity of Te oxysalt minerals (in bits per reduced unit cell). Simpler structures are indicated in violet/blue hues and most complex structures are red.

extended polymers of various dimensionalities: chains, sheets or frameworks? The crystal structures used are taken from the references that are asterisked in Table 1. Xocometatlite and eztlite, along with kuranakhite of Table 1, are necessarily excluded from this part of the investigation, as their structures are still unknown.

First, we note that there is more than one way to distinguish FBBs from interstitial components. We examine two alternatives in this paper, one that considers only the Te polyanion, while the other is broader, and includes other relatively strongly bonded cations that are linked to the $\mathrm{Te}-\mathrm{O}$ moiety. These two approaches are discussed further below.

The analogy with traditional silicate classifications, such as that of Liebau (1985), is close enough if only Te atoms and their directly-bonded anions are considered to be part of the structural unit. However, even this apparently simple strategy meets some complications.

While $\mathrm{Te}^{6+}$ is always octahedrally coordinated in the minerals of this study, and the $\mathrm{Te}-\mathrm{O}$ bonds with bond valence $s=1$ are the highest-valence bonds of the relevant structures, two $\mathrm{Te}^{6+}$ minerals have sites in which the Te is in solid solution with another element. In burckhardite, $\mathrm{Te}^{6+}$ is mixed 1:1 with $\mathrm{Fe}^{3+}$, with no evidence of long-range order (Christy et al., 2015). Markcooperite has two crystallographically distinct but topologically similar sites, one exclusively occupied by $\mathrm{Te}$, while the other is dominantly $\mathrm{U}$, but with significant Te substitution ( 25\%: Kampf et al., 2010d). The 50\% Te occupancy in burckhardtite and the equal bond valences of $\mathrm{U}-\mathrm{O}$ and $\mathrm{Te}-\mathrm{O}$ in markcooperite suggest that for this study, the $\left(\mathrm{Fe}_{0.5} \mathrm{Te}_{0.5}\right)$ and $\left(\mathrm{U}_{0.75} \mathrm{Te}_{0.25}\right)$ sites should be included in the FBB.

Further complexity is introduced by $\mathrm{Te}^{4+}$, as it possesses a stereoactive lone pair of electrons, which causes strong asymmetry in its coordination shell, with a very wide range of $\mathrm{Te}-\mathrm{O}$ bond distances and bond valences (Mills and Christy, 2013; Christy and Mills, 2013). Thus, it is necessary to define a bond-valence cut-off beyond which $\mathrm{Te}-\mathrm{O}$ links cease to be part of the FBB. The only $\mathrm{Te}^{4+}$ mineral of known structure in this study is telluroperite, in which Te shows a clear gap between four short, strong $\mathrm{Te}-\mathrm{O}$ bonds and longer $\mathrm{Te} \cdots \mathrm{Cl}$ links which are weaker in bond valence by a factor of 5-6 (Kampf et al. 2010f). Again, there is long-range disorder. The $\mathrm{Te}^{4+}$ of telluroperite shares its site in 1:1 ratio with a different cation, this time $\mathrm{Pb}^{2+}$. The $\left(\mathrm{Pb}_{0.5} \mathrm{Te}_{0.5}\right)$ site alternates with a topologically similar site that is $100 \% \mathrm{~Pb}^{2+}$, with no Te substitution. Kampf et al. (2010f) give bond distances of $2.447 \AA$ for the all $\mathrm{Pb}$ site and $2.261 \AA$ for $\left(\mathrm{Pb}_{0.5} \mathrm{Te}_{0.5}\right)$, which correspond to very different bond valences for $\mathrm{Pb}-\mathrm{O}$ of 0.37 and $0.54 \mathrm{vu}$ respectively, using the bond-valence parameters of Krivovichev and 
TABLE 2. Composition and dimensionality of structural units for the minerals of Table 1 where structure is known, using the narrower and broader criteria defined in the text. Two different types of tellurate group (dimer and monomer) occur in chromschieffelinite, but only the more complex is listed.

\begin{tabular}{|c|c|c|}
\hline Mineral & Te-only structural unit & More inclusive structural unit \\
\hline Agaite & monomer $\left[\mathrm{TeO}_{5} \mathrm{OH}\right]^{5-}(b)$ & sheet $\left[\mathrm{CuTeO}_{5} \mathrm{OH}\right]^{3-}$ \\
\hline Andychristyite & dimer $\left[\mathrm{Te}_{2} \mathrm{O}_{10}\right]^{8-}(c)$ & sheet $\left[\mathrm{Cu}_{2}\left(\mathrm{Te}_{2} \mathrm{O}_{10}\right)\right]^{4-}$ \\
\hline Bairdite & monomer $\left[\mathrm{TeO}_{5} \mathrm{OH}\right]^{5-}(b)$ & sheet $\left[\mathrm{Cu}_{4}\left(\mathrm{TeO}_{5} \mathrm{OH}\right)_{2}\right]^{2-}$ \\
\hline Burckhardtite & sheet $\left[\left(\mathrm{Fe}^{3+} \mathrm{Te}^{6+}\right) \mathrm{O}_{6}\right]^{3-}(i)$ & sheet $\left[\left(\mathrm{Fe}^{3+} \mathrm{Te}^{6+}\right) \mathrm{O}_{6}\right]^{3-}$ \\
\hline Chromschieffelinite & $\operatorname{dimer}\left[\mathrm{Te}_{2} \mathrm{O}_{8}(\mathrm{OH})_{3}\right]^{7-}(d)$ & dimer $\left[\mathrm{Te}_{2} \mathrm{O}_{8}(\mathrm{OH})_{3}\right]^{7-}$ \\
\hline Eckhardite & dimer $\left[\mathrm{Te}_{2} \mathrm{O}_{10}\right]^{8-}(c)$ & sheet $\left[\mathrm{Cu}_{2}\left(\mathrm{Te}_{2} \mathrm{O}_{10}\right)\right]^{4-}$ \\
\hline Frankhawthorneite & monomer $\left[\mathrm{TeO}_{4}(\mathrm{OH})_{2}\right]^{4-}(b)$ & framework $\left[\mathrm{Cu}_{2}\left(\mathrm{TeO}_{4}(\mathrm{OH})_{2}\right)\right]^{0}$ \\
\hline Fuettererite & monomer $\left[\mathrm{TeO}_{6}\right]^{6-}(b)$ & sheet $\left[\mathrm{Cu}_{6}\left(\mathrm{TeO}_{6}\right)(\mathrm{OH})_{6}\right]^{0}$ \\
\hline Housleyite & chain $\left[\mathrm{Te}_{4} \mathrm{O}_{18}(\mathrm{OH})_{2}\right]^{14-}(g)$ & sheet $\left[\mathrm{Cu}\left(\mathrm{Te}_{4} \mathrm{O}_{18}(\mathrm{OH})_{2}\right)\right]^{12-}$ \\
\hline Khinite & monomer $\left[\mathrm{TeO}_{6}\right]^{6-}(b)$ & sheet $\left[\mathrm{Cu}_{3}\left(\mathrm{TeO}_{6}\right)(\mathrm{OH})_{2}\right]^{2-}$ \\
\hline Kuksite & monomer $\left[\mathrm{TeO}_{6}\right]^{6-}(b)$ & framework $\left[\mathrm{Zn}_{3}\left(\mathrm{TeO}_{6}\right)\left(\mathrm{PO}_{4}\right)_{2}\right]^{6-}$ \\
\hline Markcooperite & sheet $\left[\left(\mathrm{U}_{0.75} \mathrm{Te}_{0.25}\right)^{6+} \mathrm{Te}^{6+} \mathrm{O}_{8}\right]^{4-}(h)$ & sheet $\left[\left(\mathrm{U}_{0.75} \mathrm{Te}_{0.25}\right)^{6+} \mathrm{Te}^{6+} \mathrm{O}_{8}\right]^{4-}$ \\
\hline Mcalpineite & monomer $\left[\mathrm{TeO}_{6}\right]^{6-}(b)$ & framework $\left[\mathrm{Cu}_{3} \mathrm{TeO}_{6}\right]^{0}$ \\
\hline Mojaveite & monomer $\left[\mathrm{TeO}_{4}(\mathrm{OH})_{2}\right]^{4-}(b)$ & sheet $\left[\mathrm{Cu}_{6}\left(\mathrm{TeO}_{4}(\mathrm{OH})_{2}\right)(\mathrm{OH})_{6}\right]^{2+}$ \\
\hline Ottoite & chain $\left[\mathrm{Te}_{2} \mathrm{O}_{10}\right]^{8-}(f)$ & chain $\left[\mathrm{Te}_{2} \mathrm{O}_{10}\right]^{8-}$ \\
\hline Paratimroseite & monomer $\left[\mathrm{TeO}_{6}\right]^{6-}(b)$ & sheet $\left[\mathrm{Cu}_{2}\left(\mathrm{TeO}_{6}\right)\right]^{2-}$ \\
\hline Sonoraite & monomer $\left[\mathrm{Te}^{4+} \mathrm{O}_{3}\right]^{2-}(a)$ & framework $\left[\mathrm{Fe}_{2}^{3+}\left(\mathrm{Te}^{4+} \mathrm{O}_{3}\right)_{2}(\mathrm{OH})_{2}\left(\mathrm{H}_{2} \mathrm{O}\right)\right]^{0}$ \\
\hline Telluroperite & chain $\left[\left(\mathrm{Pb}_{0.5}^{2+} \mathrm{TT}_{0.5}^{4+}\right)_{2} \mathrm{O}_{4}\right]^{2-}(e)$ & chain $\left[\left(\mathrm{Pb}_{0.5}^{2+} \mathrm{Te}_{0.5}^{4+}\right)_{2} \mathrm{O}_{4}\right]^{2-}$ \\
\hline Thorneite & dimer $\left[\mathrm{Te}_{2} \mathrm{O}_{10}\right]^{8-}(c)$ & dimer $\left[\mathrm{Te}_{2} \mathrm{O}_{10}\right]^{8-}$ (edge-sharing) \\
\hline Timroseite & monomer $\left[\mathrm{TeO}_{6}\right]^{6-}(b)$ & framework $\left[\mathrm{Cu}_{5}\left(\mathrm{TeO}_{6}\right)_{2}(\mathrm{OH})_{2}\right]^{4-}$ \\
\hline Yafsoanite & monomer $\left[\mathrm{TeO}_{6}\right]^{6-}(b)$ & framework $\left[\mathrm{Zn}_{3}\left(\mathrm{TeO}_{6}\right)_{2}\right]^{6-}$ \\
\hline
\end{tabular}

Bold indicates minerals occurring at the Bird's Nest drift.

Letter $a-i$ after the $\mathrm{Te}-\mathrm{O}$ anion gives the location of the anion in Fig. 5.

Brown (2001). This difference, along with absence of Te, justifies exclusion of the all-Pb site from the FBB. Thus, the FBB is a one-dimensional strip of edge-sharing $\left(\mathrm{Pb}_{0.5} \mathrm{Te}_{0.5}\right) \mathrm{O}_{4}$ square pyramids. The parameters of Mills and Christy (2013) estimate the $\mathrm{Te}-\mathrm{O}$ bond valence as $0.44 \mathrm{vu}$ in telluroperite, so our effective 'strong bond' threshold is below that value.

Hawthorne (2014 and references cited therein) makes use of flexible criteria to distinguish FBBs from interstitial components in a structure. For instance, for the borate minerals, Hawthorne considered only the strongly bound borate anion $(\mathrm{B}-\mathrm{O}=0.75-1.0 \mathrm{vu})$, as is performed for tellurates above. However, for anions such as phosphates and sulfates, self-polymerization is unknown or rare in minerals, so Hawthorne made much use of a more broadly defined FBB, which may contain several different cation species of relatively high bond valence. Inclusion of divalent octahedral species such as $\mathrm{Mg}^{2+}$ requires the 'strong binding' threshold to be set as low as $0.3 \mathrm{vu}$, although this is not always applied consistently. For the current study, the minerals of Table 2 contain tetrahedral $\mathrm{Zn}^{2+} \mathrm{O}_{4}(0.5 \mathrm{vu})$, octahedral $\mathrm{Fe}^{3+} \mathrm{O}_{6}(0.5 \mathrm{vu})$ and Jahn-Teller distorted $\mathrm{Cu}^{2+} \mathrm{O}_{4+2}$ (four bonds of $\sim 0.4 \mathrm{vu}$ plus two weaker bonds that are not counted), which are all potentially part of such a broader FBB, if the threshold is set at $\sim 0.4 \mathrm{vu}$. The larger divalent cations $\mathrm{Pb}^{2+}$ and $\mathrm{Ca}^{2+}$, which have many weakly-bonded ligands and usually play a channel- or interlayer-filling role, are not included as part of the structural unit.

Both types of structural unit for the Otto Mountain Te minerals are summarized in Table 2: the $\mathrm{Te}-\mathrm{O}$ moiety and the broader entity that includes additional smaller cations that are linked directly to the tellurate component. It can be seen that the $\mathrm{Te}-\mathrm{O}$ unit is always anionic overall, but can range in dimensionality from a monomer such as $\left[\mathrm{TeO}_{6}\right]^{6-}$ to several types of chain; two examples of sheets are known, but each are 'heteropolyhedral' in that they involve Te in random substitution with another cation $\left(\mathrm{Fe}^{3+}\right.$ in burckhardtite or $\mathrm{U}^{6+}$ in markcooperite). The topologies of the $\mathrm{Te}-\mathrm{O}$ anions are shown in Fig. 5. 
TABLE 3. Complexity of minerals, as measured by structural information content.

\begin{tabular}{lccc}
\hline Mineral & $N$ (atoms/unit cell) & $I_{G, \text { atom }}$ (bits/atom) & $I_{G, \text { cell }}$ (bits/cell) \\
\hline Agaite & 72 & 4.170 & 300.2 \\
Andychristyite & 22 & 3.546 & 78.0 \\
Bairdite & 60 & 3.989 & 239.3 \\
Burckhardtite & 22 & 2.651 & 58.3 \\
Chromschieffelinite & 84 & 4.953 & 416.1 \\
Eckhardite & 44 & 3.459 & 152.2 \\
Frankhawthorneite & 22 & 2.550 & 56.1 \\
Fuettererite & 70 & 3.174 & 222.2 \\
Housleyite & 66 & 4.075 & 268.9 \\
Khinite (4O polytype) & 60 & 3.907 & 234.4 \\
Kuksite & 23 & 2.281 & 52.5 \\
Markcooperite & 24 & 2.835 & 68.0 \\
Mcalpineite & 40 & 1.295 & 51.8 \\
Mojaveite & 30 & 3.409 & 102.3 \\
Ottoite & 14 & 2.236 & 31.3 \\
Paratimroseite & 52 & 3.700 & 192.4 \\
Sonoraite & 80 & 4.322 & 345.8 \\
Telluroperite & 10 & 2.122 & 21.2 \\
Thorneite & 54 & 3.412 & 184.2 \\
Timroseite & 50 & 3.969 & 198.8 \\
Yafsoanite & 80 & 1.595 & 127.6 \\
\end{tabular}

Bold indicates minerals occurring at Bird's Nest drift.

The more broadly defined structural unit that includes cations, such as $\mathrm{Cu}^{2+}$ or $\mathrm{Fe}^{3+}$, gives us an additional level of hierarchy in the classification. The dimeric tellurate anions of chromschieffelinite and thorneite, the chains of ottoite and telluroperite and the sheets of burckhardtite and markcooperite are not affected, but at this level of classification, all the other tellurate anions become parts of a larger unit with increased dimensionality, being either an infinite sheet or a framework. For instance, $\mathrm{Te}(\mathrm{O}, \mathrm{OH})_{6}$ monomers are incorporated with $\mathrm{Cu}^{2+} / \mathrm{Zn}^{2+}$ and often additional anions into infinite sheets in agaite, bairdite, fuettererite, khinite, mojaveite and paratimroseite, but into infinite frameworks in frankhawthorneite, kuksite, mcalpineite, timroseite and yafsoanite. The larger structural units are not always anionic; many of the frameworks are neutral, and while most sheets are negatively charged, that of fuettererite is neutral and that of mojaveite is cationic (Table 2).

The distribution of differently polymerized tellurate anions in the paragenetic flowchart of Fig. 2 are shown in Fig. 6. The early-crystallizing minerals all have monomeric anions, while the $\mathrm{Khn} \leftrightarrow \mathrm{Thn} \rightarrow \mathrm{Ekh} \rightarrow \mathrm{Ott} \rightarrow \mathrm{Hsl} \leftrightarrow \mathrm{Mkc}$ sequence shows a clear progression from monomer (Khn) through dimers (Thn and Ekh) and chains (Ott and $\mathrm{Hsl}$ ) to sheets (Mkc). There is an obvious analogy with Bowen's discontinuous reaction series for igneous silicate minerals, running from monomeric nesosilicates (olivine) through single-chain (pyroxene) and double-chain (amphibole) minerals to sheets (micas) and frameworks (alkali feldspar) as a function of decreasing liquidus temperature and the decreasing concentration of network-modifying small octahedral cations such as $\mathrm{Mg}^{2+}$. For the Bird Nest drift tellurates, there is no obvious correlation between anion polymerization and potential 'temperature' proxies such as water content. However, there is a rather dramatic correlation between polymerization and the content of a 'network-modifying' cation, namely $\mathrm{Cu}^{2+}$. Comparison of Fig. 6 with Fig. $4 a$ shows that all minerals with atomic $\mathrm{Cu} / \mathrm{Te}>1$ have monomeric tellurate anions, while all minerals with lower $\mathrm{Cu} / \mathrm{Te}$ or no $\mathrm{Cu}$ have more polymerized tellurate groups. The $\mathrm{Pb} / \mathrm{Te}$ ratio (Fig. $4 b$ ) does not correlate with structure. Note that although the crystallization sequence from silicate melts may also reflect resorptional equilibria between early crystals and 
melt, which are not evidenced in our system, the correlation of melt temperature with composition and structure remains valid.

The distribution of the greater structural units including non-Te cations is shown in Fig. 7. Note that almost all structural units are now sheets, and the distribution of other dimensionalities is rather haphazard, although one could believe that the most polymerized $\mathrm{Cu}-\mathrm{Te}-\mathrm{O}$ units (frameworks) occur early in the sequence, in contrast to the conclusion reached above for tellurate anions. The latter idea would be consistent with the pattern noted by Hawthorne (1992) for $\mathrm{Mg}-\mathrm{S}-\mathrm{O}$ structural units in evaporite sulfate minerals. There, the earliest-crystallizing, least-soluble minerals have infinite frameworks (langbeinite and löweite) or sheets (vanthoffite), while the last minerals to crystallize have isolated $\mathrm{SO}_{4}^{2-}$ anions and $[\mathrm{Mg}$ $\left.\left(\mathrm{H}_{2} \mathrm{O}\right)_{6}\right]^{2+}$ cations (epsomite and picromerite). The decrease in dimensionality correlates with increasing content of structural $\mathrm{H}_{2} \mathrm{O}$, which blocks polymerization and hence acts as a networkmodifying ligand in this system. As noted above, water content plays no obvious controlling role for the tellurates of this study, where anhydrous structural units occur both early in the sequence (mcalpineite) and late (markcooperite), while the most hydrated species, such as fuettererite and mojaveite, appear to be intermediate in timing, and to have grown from a highly saline fluid.

For Te oxysalt minerals such as those of the current study, the smaller Te-only structural unit appears to be a better choice than the greater unit, if we want to look for polymerization-paragenesis relationships. In this respect, they are more similar to rock-forming silicates than to the evaporite sulfates of Hawthorne (1992).

\section{Complexity}

As noted earlier, Krivovichev (2013a) defined the information content of a crystal structure as a quantitative measure of its complexity. $\mathrm{He}$ discussed several variants of this approach. For instance, the complexity may be expressed per atom or per (reduced) unit cell, and the constituents of the structure that are considered may or may not include all crystallographic sites, distinguish different occupants of a site or distinguish topologically similar sites. Complexity may also be measured for bonds between atoms, as well as or instead of the atoms themselves. Krivovichev (2013a) discussed the case of pegmatite phosphate minerals, where hydrothermal alteration of phosphates, at progressively lower temperatures, resulted in a succession of species which tended to show increasing structural complexity. This suggested that structural complexity be examined for the Te oxysalt minerals of the Bird Nest drift.

Structural complexity was calculated for the chemical compositions of Table 1. Multiplicities and occupancies of crystallographic sites were considered, but not bonds between sites. The formula unit taken was the content of a reduced primitive unit cell, which may be a multiple of the formula given in Table 1; the total number of atoms per primitive cell is given in Table 3. Let this formula contain $k$ chemical species (i.e. distinct elements in distinguishable valence states) and the cell contains $n$ distinct crystallographic sites of nonzero total occupancy. The $i^{\text {th }}$ site has multiplicity $m_{i}$ in the cell, and is occupied by fractions $f_{i j}$ of the $j^{\text {th }}$ species. The total number of atoms in the primitive unit cell is then $N=\Sigma_{i j} m_{i} f_{i j}$, and the proportion of atoms represented by the $j^{\text {th }}$ species on the $i^{\text {th }}$ site is $p_{i j}=m_{i} f_{i j} / N$. The structural complexity, measured in bits of information per atom, is then $I_{G \text {,atom }}=$ $-\Sigma_{i j} p_{i j} \log _{2} p_{i j}$, and the total complexity per reduced unit cell $=I_{G \text {,cell }}=N \times I_{G \text {,atom. }}$. These complexity parameters have been calculated for the minerals of Table 2, and are listed in Table 3.

The number of atoms per reduced unit cell $N$ ranges from 10 for the very simple structure of telluroperite up to 80 or more for cases like chromschieffelinite (many distinct crystallographic sites in low-symmetry cell) and yafsoanite (small number of sites with high multiplicities in nonsymmorphic cubic space group $I a-\overline{3} d$ ). Complexity per atom varies by a factor of $\sim 3$, from $1.2-1.6$ for parsimonious structures with cubic symmetry (mcalpineite and yafsoanite) to 4-5 for complex structures of low symmetry (with chromschieffelinite as the extreme example). Except for the two cubic structures, there is a rather strong positive correlation between $N$ and $I_{G \text {,atom, which in turn }}$ leads to a similar correlation between $N$ or $I_{G \text {,atom }}$ and $I_{G \text {,cell }}$. The unit-cell complexity varies by a factor of 20, from 21 bits/cell for the simple structure of telluroperite to 416 bits/cell for moderately complex chromschieffelinite. All of these values are in the 'simple' $\left(I_{G \text {,cell }}=20-100\right)$ or 'intermediate' (100-500) categories of Krivovichev (2013a); none approach the complexity of tectosilicates with large unit cells, such as paulingite (6767 bits/cell).

For the Te oxysalt minerals, there appears to be no systematic variation of complexity with paragenetic 
sequence. It can be seen in Fig. 8 that simple minerals may occur at any position in the sequence, as exemplified by early mcalpineite ( 52 bits/cell), intermediate telluroperite (21) and late ottoite (31). The same is true for the most complex minerals, such as early khinite (234), intermediate chromschieffelinite (416) and late housleyite (269). Other factors are clearly dominant in determining the topology of Fig. 2. The lack of correlation with information complexity probably reflects the narrow range of temperature and pressure over which the Bird Nest Drift minerals formed; similarly poor correlation was noted for low-temperature zeolite minerals by Krivovichev (2013b).

\section{Conclusions}

The Bird Nest drift, on Otto Mountain, is a locality with an unusual diversity of secondary Te oxysalt minerals. Observations of overgrowth relationships from this locality allowed partial paragenetic sequences to be established, which were united into a single 'flowchart' for all 18 species plus spatial association data and data from other localities. Apart from $\mathrm{Te}$ and $\mathrm{O}$, the components $\mathrm{Pb}, \mathrm{Cu}$ and $\mathrm{H}$ are essential in the majority of the minerals; eight of the minerals belong completely to the $\mathrm{Pb}-\mathrm{Cu}-\mathrm{Te}-\mathrm{O}-\mathrm{H}$ system or a subsystem thereof. There is a tendency for atomic $\mathrm{Cu} / \mathrm{Te}$ to decrease through the paragenetic sequence. This, and the occurrence of minerals with additional components such as $\mathrm{Cl}^{-}, \mathrm{CO}_{3}^{2-}, \mathrm{SO}_{4}^{2-}$ and $\mathrm{Fe}^{3+}$ at an intermediate stage, suggests that the parent fluids evolved through time in a fashion that was not monotonic, and reflected different spatial distributions and accessibility for sources of the various components.

For the minerals with known crystal structures, two alternative 'structural units' were identified, one consisting only of the Te oxyanion, while the other also included small, strongly-bound cations such as $\mathrm{Cu}^{2+}$. Both showed a range of polymerization states, but only the more narrowly-defined structural unit correlated with paragenetic sequence: the monomeric $\mathrm{Te}(\mathrm{O}, \mathrm{OH})_{6}$ anions of early minerals evolving through dimeric and chain types to sheet structures. This may be related to the decrease in activity of the 'network-modifying' cation $\mathrm{Cu}^{2+}$, further strengthening the analogy with Bowen's discontinuous reaction series in igneous rock-forming silicates.

No relationship was seen between paragenetic order and the larger type of structural unit, or structural complexity as defined by information content. This contrasts with results obtained by
Hawthorne (1992) for evaporite sulfates and Krivovichev (2013a) for pegmatite phosphates, and implies that while structure-paragenesis relationships may be widespread, the exact nature of such relationships may be different for different chemical systems and different paragenetic environments.

In principle, it would be possible to model crystallization sequences of minerals such as the Bird Nest drift tellurates, if thermodynamic properties were known for the minerals and for the species dissolved in aqueous solution. Precipitating phases could be predicted from known fluid compositions and temperatures and, conversely, the observed assemblage, assumed to represent local equilibrium, could constrain fluid conditions. Unfortunately, the thermodynamic data available for Te compounds and complexes remains very limited (cf. Grundler et al., 2013). Further study is clearly justified, given that Te forms the largest number of mineral species of any element relative to its crustal abundance (Christy, 2015), shows an enormous diversity of crystal structural architecture in its minerals and synthetic compounds, whole groups of which are of interest for their photonic and fast-ion conduction properties (Christy et al., 2016), and is frequently an indicator of economic gold deposits in the crust (Cook et al., 2009).

\section{Acknowledgements}

The authors thank two anonymous reviewers for helpful suggestions which improved the manuscript. Part of this study has been funded by The Ian Potter Foundation grant 'tracking tellurium' to SJM which is gratefully acknowledged. X-ray diffraction identification of species was funded by the John Jago Trelawney Endowment to the Mineral Sciences Department of the Natural History Museum of Los Angeles County and microprobe and Raman identification were funded by a grant from the Northern California Mineralogical Association. Jerry Baird is thanked for providing the picture of frankhawthorneite on khinite.

\section{References}

Birch, W.D. (1993) Phosphate minerals in granitic rocks. Pp. 5-40 in: Phosphate Minerals of Victoria (W.D. Birch and D.A. Henry, editors). Special Publication no. 3. The Mineralogical Society of Victoria, Melbourne, Australia.

Birch, W.D. and Van der Heyden, A. (1988) Minerals from the Kintore Opencut, Broken Hill, New South Wales. Mineralogical Record, 19, 425-436. 
Birch, W.D., Mills, S.J., Maas, R. and Hellstrom, J.C. (2011) A chronology for Late Quaternary weathering in the Murray Basin, southeastern Australia: evidence from ${ }^{230} \mathrm{Th} / \mathrm{U}$ dating of secondary uranium phosphates in the Lake Boga and Wycheproof granites, Victoria. Australian Joutrnal of Earth Sciences, 58, 835-845.

Bottinga, Y. and Weill, D.F. (1972) The viscosity of magmatic silicate liquids: a model for calculation. American Journal of Science, 272, 438-475.

Bowen, N.L. (1922) The reaction principle in petrogenesis. Journal of Geology, 30, 177-198.

Bragg, W.L. (1930) The structure of silicates. Zeitschrift für Kristallographie, 74, 237-305.

Brown, I.D. (1981) The bond-valence method: an empirical approach to chemical structure and bonding. Pp. 1-30. in: Structure and Bonding in Crystals (M. O'Keeffe and A. Navrotsky, editors). Vol. 2. Academic Press, New York.

Burns, P.C. (1995) Borate clusters and fundamental building blocks containing four polyhedra: why few clusters are utilized as fundamental building blocks of structures. The Canadian Mineralogist, 33, 1167-1176.

Burns, P.C., Cooper, M.A. and Hawthorne, F.C. (1995) Parakhinite, $\mathrm{Cu}_{3}^{2+} \mathrm{Pb}^{2+} \mathrm{Te}^{6+} \mathrm{O}_{6}(\mathrm{OH})_{2}$ : crystal structure and revision of the chemical formula. The Canadian Mineralogist, 33, 33-40.

Carbone, C., Basso, R., Cabella, R., Martinelli, A., Grice, J.D. and Lucchetti, G. (2013) Mcalpineite from the Gambatesa mine, Itraly, and redefinition of the species. American Mineralogist, 98, 1899-1905.

Christ, C.L. (1960) Crystal chemistry and systematic classification of hydrated borate minerals. American Mineralogist, 45, 334-340.

Christy, A.G. (2015) Causes of anomalous mineralogical diversity in the Periodic Table. Mineralogical Magazine, 79, 33-49.

Christy, A.G. and Mills, S.J. (2013) Effect of lone-pair stereoactivity on polyhedral volume and structural flexibility: application to $\mathrm{Te}^{\mathrm{IV}} \mathrm{O}_{6}$ octahedra. Acta Crystallographica, B69, 446-456.

Christy, A.G., Kampf, A.R., Mills, S.J., Housley, R.M. and Thorne, B. (2015) Crystal structure and revised chemical formula for burckhardtite, $\mathrm{Pb}_{2}\left(\mathrm{Fe}^{3+} \mathrm{Te}^{6+}\right)$ $\left[\mathrm{AlSi}_{3} \mathrm{O}_{8}\right] \mathrm{O}_{6}$ : a double-sheet silicate with intercalated phyllotellurate layers. Mineralogical Magazine, 78, 1763-1773.

Christy, A.G., Mills, S.J. and Kampf, A.R. (2016) A review of the structural architecture of tellurium oxycompounds. Mineralogical Magazine, 80, doi: 10.1180/minmag.2016.080.093

Cook, N.J., Ciobanu, C.J., Spry, P.G. and Voudouris, P. (2009) Understanding gold-(silver)-telluride-(selenide) mineral deposits. Episodes, 32, 249-263.

Cooper, M.A., Hawthorne, F.C. and Back, M.E. (2008) The crystal structure of khinite and polytypism in khinite and parakhinite. Mineralogical Magazine, 72, 763-770.

Estevez-Rams, E. and González-Férez, R. (2009) On the concept of long-range order in solids: the use of algorithmic complexity. Zeitschrift für Kristallographie, 224, 179-184.

Grice, J.D. and Roberts, A.C. (1995) Frankhawthorneite, a unique HCP framework structure of a cupric tellurate. The Canadian Mineralogist, 33, 649-654.

Grundler, P.V., Brugger, J., Etschmann, B.E., Helm, L., Liu, W., Spry, P.G., Tian, Y., Testemale, D. and Pring, A. (2013) Speciation of aqueous tellurium(IV) in hydrothermal solutions and vapors, and the role of oxidized tellurium species in Te transport and gold deposition. Geochimica et Cosmochimica Acta, 120, 298-325.

Hawthorne, F.C. (1979) The crystal structure of morinite. The Canadian Mineralogist, 17, 93-102.

Hawthorne, F.C. (1983) Graphical enumeration of polyhedral clusters. Acta Crystallographica, A39, 724-736.

Hawthorne, F.C. (1985) Towards a structural classification of minerals: the ${ }^{\mathrm{vi}} M^{\mathrm{iv}} T_{2} \mathrm{O}_{n}$ minerals. American Mineralogist, 70, 455-473.

Hawthorne, F.C. (1990) Structural hierarchy in $M^{[6]} T^{[4]} \varphi_{n}$ minerals. Zeitschrift für Kristallographie, 192, 1-52.

Hawthorne, F.C. (1992) Bond topology, bond valence and structure stability. Pp. 25-87 in: The Stability of Minerals (G.D. Price and N.L. Ross, editors). Mineralogical Society Series, vol. 3. Chapman and Hall, London.

Hawthorne, F.C. (2014) The structure hierarchy hypothesis. Mineralogical Magazine, 78, 957-1027.

Hawthorne, F.C., Cooper, M.A. and Back, M.E. (2009) Khinite-4O (= khinite) and khinite-3 $T$ (= parakhinite). The Canadian Mineralogist, 47, 473-476.

Housley, R.M., Kampf, A.R., Mills, S.J., Marty, J. and Thorne, B. (2011) The remarkable occurrence of rare secondary minerals at Otto Mountain near Baker, California - including seven new species. Rocks \& Minerals, 86(2), 132-142.

Jonsson, E. and Broman, C. (2002) Fluid inclusions in late-stage $\mathrm{Pb}-\mathrm{Mn}-\mathrm{As}-\mathrm{Sb}$ mineral assemblages in the Långban deposit, Bergslagen, Sweden. The Canadian Mineralogist, 40, 47-65.

Kampf, A.R., Housley, R.M., Mills, S.J., Marty, J. and Thorne, B. (2010a) Lead-tellurium oxysalts from Otto Mountain near Baker, California: I. Ottoite, $\mathrm{Pb}_{2} \mathrm{TeO}_{5}$, a new mineral with chains of tellurate octahedra. American Mineralogist, 95, 1329-1336.

Kampf, A.R., Marty, J. and Thorne, B. (2010b) Leadtellurium oxysalts from Otto Mountain near Baker, California: II. Housleyite, $\mathrm{Pb}_{6} \mathrm{CuTe}_{4} \mathrm{O}_{18}(\mathrm{OH})_{2}$, a new mineral with $\mathrm{Cu}-\mathrm{Te}$ octahedral sheets. American Mineralogist, 95, 1337-1342.

Kampf, A.R., Housley, R.M. and Marty, J. (2010c) Leadtellurium oxysalts from Otto Mountain near Baker, 
California: III. Thorneite, $\mathrm{Pb}_{6}\left(\mathrm{Te}_{2}^{6+} \mathrm{O}_{10}\right)\left(\mathrm{CO}_{3}\right)$ $\mathrm{Cl}_{2}\left(\mathrm{H}_{2} \mathrm{O}\right)$, the first mineral with edge-sharing octahedral tellurate dimers. American Mineralogist, 95, 1548-1553.

Kampf, A.R., Mills, S.J., Housley, R.M., Marty, J. and Thorne, B. (2010d) Lead-tellurium oxysalts from Otto Mountain near Baker, California: IV. Markcooperite, $\mathrm{Pb}\left(\mathrm{UO}_{2}\right) \mathrm{Te}^{6+} \mathrm{O}_{6}$, the first natural uranyl tellurate. American Mineralogist, 95, 1554-1559.

Kampf, A.R., Mills, S.J., Housley, R.M., Marty, J. and Thorne, B. (2010e) Lead-tellurium oxysalts from Otto Mountain near Baker, California: V. Timroseite, $\mathrm{Pb}_{2} \mathrm{Cu}_{5}^{2+}\left(\mathrm{Te}^{6+} \mathrm{O}_{6}\right)_{2}(\mathrm{OH})_{2}$, and paratimroseite, $\mathrm{Pb}_{2} \mathrm{Cu}_{4}^{2+}$ $\left(\mathrm{Te}^{6+} \mathrm{O}_{6}\right)_{2}\left(\mathrm{H}_{2} \mathrm{O}\right)_{2}$, two new tellurates with $\mathrm{Te}-\mathrm{Cu}$ polyhedral sheets. American Mineralogist, 95, 1560-1568.

Kampf, A.R., Mills, S.J., Housley, R.M., Marty, J. and Thorne, B. (2010 $f$ ) Lead-tellurium oxysalts from Otto Mountain near Baker, California: VI. Telluroperite, $\mathrm{Pb}_{3} \mathrm{Te}^{4+} \mathrm{O}_{4} \mathrm{Cl}_{2}$, the $\mathrm{Te}$ analog of perite and nadorite. American Mineralogist, 95, 1569-1573.

Kampf, A.R., Mills, S.J., Housley, R.M., Rumsey, M.S. and Spratt, J. (2012) Lead-tellurium oxysalts from Otto Mountain near Baker, California: VII. Chromschieffelinite, $\mathrm{Pb}_{10} \mathrm{Te}_{6} \mathrm{O}_{20}(\mathrm{OH})_{14}\left(\mathrm{CrO}_{4}\right)\left(\mathrm{H}_{2} \mathrm{O}\right)_{5}$, the chromate analog of schieffelinite. American Mineralogist, 97, 212-219.

Kampf, A.R., Mills, S.J., Housley, R.M. and Marty, J. (2013a) Lead-tellurium oxysalts from Otto Mountain near Baker, California: VIII. Fuettererite, $\mathrm{Pb}_{3} \mathrm{Cu}_{6}^{2+}$ $\mathrm{Te}^{6+} \mathrm{O}_{6}(\mathrm{OH})_{7} \mathrm{Cl}_{5}$, a new mineral with double spangolite-type sheets. American Mineralogist, 98, 506-511.

Kampf, A.R., Mills, S.J., Housley, R.M. and Marty, J. (2013b) Lead-tellurium oxysalts from Otto Mountain near Baker, California: IX. Agaite, $\mathrm{Pb}_{3} \mathrm{Cu}^{2+}$ $\mathrm{Te}^{6+} \mathrm{O}_{5}(\mathrm{OH})_{2}\left(\mathrm{CO}_{3}\right)$, a new mineral with $\mathrm{CuO}_{5}-\mathrm{TeO}_{6}$ polyhedral sheets. American Mineralogist, 98, 512-517.

Kampf, A.R., Mills, S.J., Housley, R.M., Rossman, G.R., Marty, J. and Thorne, B. (2013c) Lead-tellurium oxysalts from Otto Mountain near Baker, California: X. Bairdite, $\mathrm{Pb}_{2} \mathrm{Cu}_{4}^{2+} \mathrm{Te}_{2}^{6+} \mathrm{O}_{10}(\mathrm{OH})_{2}\left(\mathrm{SO}_{4}\right)\left(\mathrm{H}_{2} \mathrm{O}\right)$, a new mineral with thick HCP layers. American Mineralogist, 98, 1315-1321.

Kampf, A.R., Mills, S.J., Housley, R.M., Rossman, G.R., Marty, J. and Thorne, B. (2013d) Lead-tellurium oxysalts from Otto Mountain near Baker, California: XI. Eckhardite, $(\mathrm{Ca}, \mathrm{Pb}) \mathrm{Cu}^{2+} \mathrm{Te}^{6+} \mathrm{O}_{5}\left(\mathrm{H}_{2} \mathrm{O}\right)$, a new mineral with HCP stair-step layers. American Mineralogist, 98, 1617-1623.

Kampf, A.R., Cooper, M.A., Mills, S.J., Housley, R.M. and Rossman, G.R. (2016) Lead-tellurium oxysalts from Otto Mountain near Baker, California: XII. Andychristyite, $\mathrm{PbCu}^{2+} \mathrm{Te}^{6+} \mathrm{O}_{5}\left(\mathrm{H}_{2} \mathrm{O}\right)$, a new mineral with HCP stair-step layers. Mineralogical Magazine, 80, prepublication doi: 10.1180/minmag.2016.080.042.
Keller, P. (1977) Tsumeb, VI Paragenesis. Mineralogical Record, 8, 36-47.

Kretz, R. (1983) Symbols for rock-forming minerals. American Mineralogist, 68, 277-279.

Krivovichev, S.V. (2013a) Structural complexity of minerals: information storage and processing in the mineral world. Mineralogical Magazine, 77, 275-326.

Krivovichev, S.V. (2013b) Structural and topological complexity of zeolites: an information-theoretic analysis. Microporous and Mesoporous Materials, 171, 223-229.

Krivovichev, S.V. (2014) On the algorithmic complexity of crystals. Mineralogical Magazine, 78, 415-435.

Krivovichev, S.V. and Brown, I.D. (2001) Are the compressive effects of encapsulation an artifact of the bond valence parameters? Zeitschrift für Kristallographie, 216, 245-247.

Krivovichev, S.V., Mentré, O., Siidra, O.I., Colmont, M., Filatov, S.K. (2013) Anion-centred tetrahedra in inorganic compounds. Chemical Reviews, 113, 6459-6535.

Larsen, E.S. (1942) The mineralogy and paragenesis of the variscite nodules from near Fairfield, Utah. Part 2. American Mineralogist, 27, 350-372.

Liebau, F. (1985) Structural Chemistry of Silicates. Springer-Verlag, Heidelberg, Berlin, New York, Tokyo. 347 pp.

Magnusson, N.H. (1930) Långbans malmtrakt: geologisk beskrivning. Sveriges geologiska undersökning, Series Ca: Avhandlingar och uppsatser, 2v3, 111 pp.

McLaughlin, T.G. (1940) Pegmatite dikes of the Bridger Mountains, Wyoming. American Mineralogist, 25, 46-68.

Mills, S.J. and Christy, A.G. (2013) Revised values of the bond valence parameters for $\mathrm{Te}^{\mathrm{IV}}-\mathrm{O}, \mathrm{Te}^{\mathrm{VI}}-\mathrm{O}$ and $\mathrm{Te}^{\mathrm{IV}}-\mathrm{Cl}$. Acta Crystallographica, B69, 145-149.

Mills, S.J., Birch, W.D., Maas, R., Phillips, D. and Plimer, I.R. (2008) Lake Boga granite, northwestern Victoria: mineralogy, geochemistry and geochronology. Australian Journal of Earth Sciences, 55, 281-299.

Mills, S.J., Kampf, A.R., Kolitsch, U., Houstey, R.M. and Raudsepp, M. (2010) The crystal chemistry and crystal structure of kuksite, $\mathrm{Pb}_{3} \mathrm{Zn}_{3} \mathrm{Te}^{6+} \mathrm{P}_{2} \mathrm{O}_{14}$, and a note on the crystal structure of yafsoanite, $(\mathrm{Ca}$, $\mathrm{Pb})_{3} \mathrm{Zn}_{3}\left(\mathrm{TeO}_{6}\right)_{2}$. American Mineralogist, 95, 933-938.

Mills, S.J., Kampf, A.R., Christy, A.G., Housley, R.M., Rossman, G.R., Reynolds, R.E. and Marty, J. (2014) Mojaveite and bluebellite, two new minerals from the central Mojave Desert, California, USA. Mineralogical Magazine, 78, 1325-1340.

Moore, P.B. (1970a) Mineralogy and chemistry of Långban-type ore deposits in Bergslagen, Sweden. Mineralogical Record, 1, 154-172.

Moore, P.B. (1970b) A crystal-chemical basis for short transition series orthophosphate and orthoarsenate 


\section{ANDREW G. CHRISTY ETAL.}

parageneses. Neues Jahrbuch für Mineralogie Monatshefte, 1970, 39-44.

Moore, P.B. (1970c) Structural hierarchies among minerals containing octahedrally coordinating oxygen: I. Stereoisomerism among corner-sharing octahedral and tetarhedral chains. Neues Jahrbuch für Mineralogie Monatshefte, 1970, 163-173.

Moore, P.B. (1973) Pegmatite phosphates: descriptive mineralogy and crystal chemistry. Mineralogical Record, 4, 103-130.

Moore, P.B. (1982) Pegmatite minerals of P(V) and B(III). Pp. 267-291 in: Granitic Pegmatites in Science and Industry (P. Černý, editor). Mineralogical Association of Canada Short Course, 8, Mineralogical Association of Canada, Québec, Canada.

Moore, P.B. (1984) Crystallochemical aspects of the phosphate minerals. Pp. 155-170 in: Phosphate Minerals (J.O. Nriagu and P.B. Moore, editors). Springer-Verlag. Berlin, Heidelberg, New York, Tokyo.

Mysen, B.O. (1983) The structure of silicate melts. Annual Review of Earth and Planetary Sciences, 11, 75-97.

Pabst, A. (1950) A structural classification of fluoaluminates. American Mineralogist, 35, 149-165.

Roberts, A.C., Grice, J.D., Criddle, A.J., Jensen, M.C., Harris, D.C. and Moffatt, E.A. (1995) Frankhawthorneite, $\mathrm{Cu}_{2} \mathrm{Te}^{6+} \mathrm{O}_{4}(\mathrm{OH})_{2}$, a new mineral species from the Centennial Eureka mine, Tintic District, Juab County, Utah. The Canadian Mineralogist, 33, 641-647.
Schindler, M. and Hawthorne, F.C. (2001a) A bondvalence approach to the structure, chemistry and paragenesis of hydroxy-hydrated oxysalt minerals. I. Theory. The Canadian Mineralogist, 39, 1225-1242.

Schindler, M. and Hawthorne, F.C. (2001b) A bondvalence approach to the structure, chemistry and paragenesis of hydroxy-hydrated oxysalt minerals. II. Crystal structure and chemical composition of borate minerals. The Canadian Mineralogist, 39, 1243-1256.

Schindler, M. and Hawthorne, F.C. (2001c) A bondvalence approach to the structure, chemistry and paragenesis of hydroxy-hydrated oxysalt minerals. III. Paragensis of borate minerals. The Canadian Mineralogist, 39, 1257-1274.

Schindler, M. and Hawthorne, F.C. (2004) A bondvalence approach to the uranyl-oxide hydroxy-hydrate minerals: chemical composition and occurrence. The Canadian Mineralogist, 42, 1601-1627.

Schindler, M., Hawthorne, F.C. and Baur, W.H. (2000) A crystal chemical approach to the composition and occurrence of vanadium minerals. The Canadian Mineralogist, 38, 1443-1456.

Steurer, W. (2011) Measures of complexity. Acta Crystallographica, A67, C184.

Warren, B.E. and Pincus, A.G. (1940) Atomic consideration of immiscibility in glass systems. Journal of the American Ceramic Society, 23, 301-304.

Whitney, D.L. and Evans, B.W. (2010) Abbreviations for names of rock-forming minerals. American Mineralogist, 95, 185-187. 